\title{
Wheat root systems as a breeding target for climate resilience
}

\author{
Eric S. Ober ${ }^{1}$ (D) Samir Alahmad ${ }^{2}$. James Cockram ${ }^{1} \cdot$ Cristian Forestan $^{3} \cdot$ Lee T. Hickey ${ }^{2} \cdot$ Josefine Kant $^{4}$. \\ Marco Maccaferri ${ }^{3}$. Emily Marr ${ }^{1} \cdot$ Matthew Milner $^{1} \cdot$ Francisco Pinto $^{5}$. Charlotte Rambla ${ }^{2} \cdot$ Matthew Reynolds $^{5}$. \\ Silvio Salvi ${ }^{3} \cdot$ Giuseppe Sciara $^{3} \cdot$ Rod J. Snowdon ${ }^{6} \cdot$ Pauline Thomelin $^{1} \cdot$ Roberto Tuberosa $^{3} \cdot$ Cristobal Uauy $^{7}$. \\ Kai P. Voss-Fels ${ }^{8} \cdot$ Emma Wallington $^{1} \cdot$ Michelle Watt $^{9}$
}

Received: 11 January 2021 / Accepted: 18 March 2021 / Published online: 26 April 2021

(c) The Author(s) 2021

\begin{abstract}
In the coming decades, larger genetic gains in yield will be necessary to meet projected demand, and this must be achieved despite the destabilizing impacts of climate change on crop production. The root systems of crops capture the water and nutrients needed to support crop growth, and improved root systems tailored to the challenges of specific agricultural environments could improve climate resiliency. Each component of root initiation, growth and development is controlled genetically and responds to the environment, which translates to a complex quantitative system to navigate for the breeder, but also a world of opportunity given the right tools. In this review, we argue that it is important to know more about the 'hidden half' of crop plants and hypothesize that crop improvement could be further enhanced using approaches that directly target selection for root system architecture. To explore these issues, we focus predominantly on bread wheat (Triticum aestivum L.), a staple crop that plays a major role in underpinning global food security. We review the tools available for root phenotyping under controlled and field conditions and the use of these platforms alongside modern genetics and genomics resources to dissect the genetic architecture controlling the wheat root system. To contextualize these advances for applied wheat breeding, we explore questions surrounding which root system architectures should be selected for, which agricultural environments and genetic trait configurations of breeding populations are these best suited to, and how might direct selection for these root ideotypes be implemented in practice.
\end{abstract}

\section{Abbreviations}

ERT Electrical resistance tomography

EMI Electromagnetic inductance

GSA Gravitropic setpoint angle

GWAS Genome-wide association study
KASP Kompetitive allele-specific PCR

NIL Near-isogenic line

QTL Quantitative trait locus

RSA Root system architecture

SNP Single nucleotide polymorphism
Communicated by Peter Langridge.

Eric S. Ober

eric.ober@niab.com

1 NIAB, 93 Lawrence Weaver Road, Cambridge CB3 OLE, $\mathrm{UK}$

2 Centre for Crop Science, Queensland Alliance for Agriculture and Food Innovation, The University of Queensland, Brisbane, QLD 4072, Australia

3 Department of Agricultural and Food Sciences, University of Bologna, Viale G Fanin 44, 40127 Bologna, Italy

4 Forschungszentrum Jülich, IBG-2, Wilhelm-Johnen-Straße, 52428 Jülich, Germany

5 Global Wheat Program, International Maize and Wheat Improvement Center (CIMMYT), 56237 Texcoco, Estado de Mexico, Mexico
6 Department of Plant Breeding, IFZ Research Centre for Biosystems, Land Use and Nutrition, Justus Liebig University, Heinrich-Buff-Ring 26-32, 35392 Giessen, Germany

7 John Innes Centre, Norwich Research Park, Colney Lane, Norwich NR4 7UH, UK

8 Centre for Animal Science, Queensland Alliance for Agriculture and Food Innovation, The University of Queensland, Brisbane, QLD 4072, Australia

9 School of BioSciences, University of Melbourne, Parkville, VIC 3010, Australia 


\section{Food security and crop root systems}

Wheat, which supplies approximately $20 \%$ of human calories and protein, is vitally important for global food security (Tadesse et al. 2019), yet in some years global stocksto-use ratios have reached critical levels (Bobenrieth et al. 2013). It has been estimated that the current relative rate of genetic gain of $1 \%$ per annum is insufficient to match the projected demand of an increasing human population by 2050 (Hickey et al. 2019; Hall and Richards 2013), and this is exacerbated by climate change (Asseng et al. 2015). Thus, there is a pressing need to adopt technologies that can accelerate the rate of genetic gain in important food crops (Lenaerts et al. 2019; Cobb et al. 2019).

Historically, the consistent incremental gains delivered by modern cereal breeding have relied predominantly on direct visual selection for improved performance, and this has almost exclusively been based on assessment of the above-ground parts of the plant. This overlooks direct selection of the root system, due to the practical difficulties in assessing the 'hidden half' of crop plants (Bishopp and Lynch 2015). Roots are fundamentally important for the plant, mediating the water and nutrient uptake required for growth, and are a source of chemical and hydraulic signals that modulate shoot growth and physiology. In many published studies on crop root systems, it is common to find the suggestion that certain root traits should be selected in breeding programmes, but without further note on how that would happen. In contrast, there is a popular notion that breeding for optimizing root systems of crop species is too difficult and/or expensive. Recent research is showing that breeding for improved root systems is increasingly feasible, with development of tangible tools such as high-throughput phenotyping systems and molecular markers that pre-breeders and breeders can use in practice (Munns et al. 2012; Wasson et al. 2020). Nevertheless, there are few published reports of released cultivars grown by farmers that have been developed with specific selections for root traits (excepting root crop species). One notable example is the upland rice cultivar PY84, which was developed using marker-assisted selection for four quantitative trait loci (QTL) controlling deeper rooting and improved drought tolerance, and which is now grown by farmers in Eastern India (Steele et al. 2013; Steele (personal communication)).

Validation of the phenotypes targeted by crop breeding programmes within real-life production environments is essential (Passioura 2012), and for obvious reasons it is particularly challenging to observe roots in situ in the field. However, root system architecture (RSA, the spatial and temporal colonization of roots in the soil; Fig. 1) is clearly important for acquiring soil resources when they are limiting (Lynch 1995). Notable examples are root proliferation in superficial soil layers for P acquisition (Lynch 2019; Henry et al. 2010), placement of roots in deep soil layers to access moisture during drought (Lopes and Reynolds 2010; Hurd 1974; Kirkegaard et al. 2007; Rich et al. 2016) and a strong root plate to minimize lodging (Dreccer et al. 2020; Piñera et al. 2016). However, it is not necessarily obvious what RSA ideotype is needed to achieve the greatest gains in crop yield potential; i.e. the yields obtained under optimal growing conditions (not limited by water, nutrients, light, etc.). Thanks to modern varieties, agricultural practices, machinery and technology, farmers are able to produce outstanding yields under the best conditions. For example, the 2020
Fig. 1 Diagram illustrating root system architectures of wheat. a Principal features of the wheat root architecture. b An example of different root ideotypes that can be generated by combining different genetic loci controlling root angle and root biomass. Image was created with Biorender.com

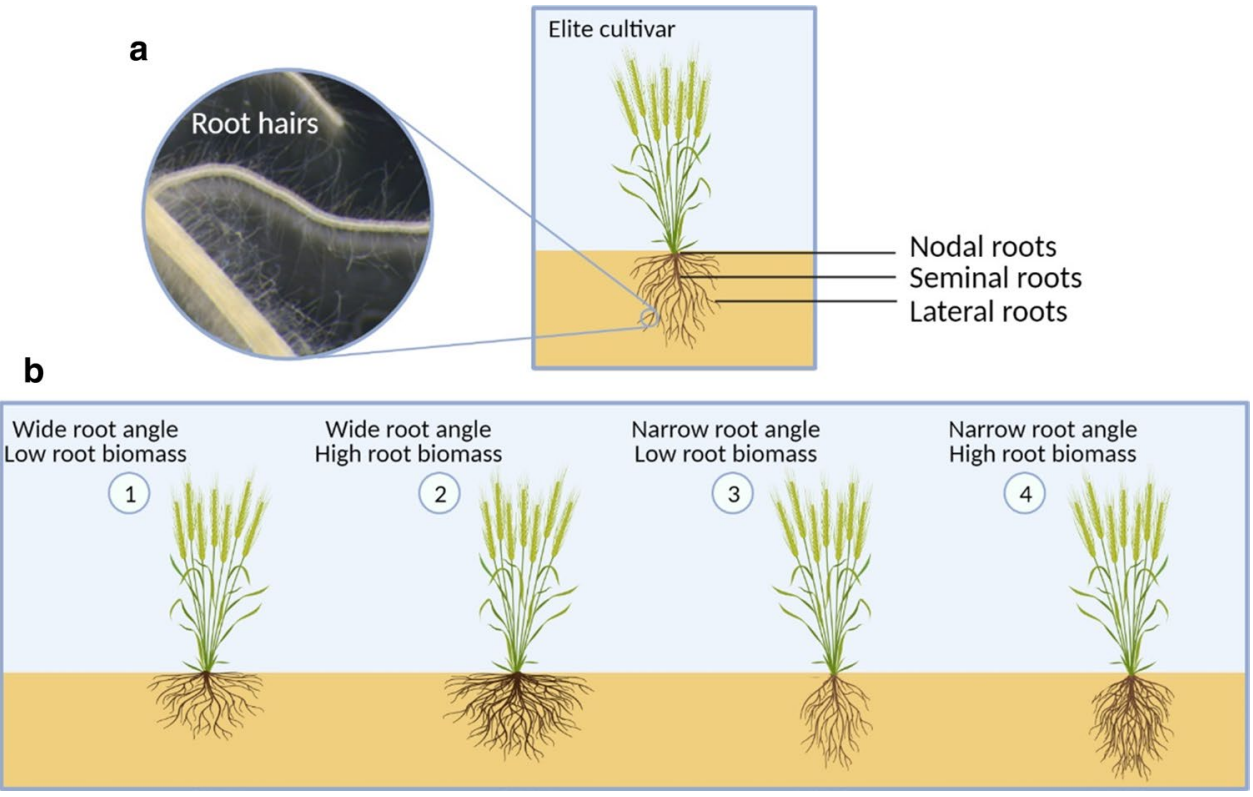


world record for wheat grain yield was $17.389 \mathrm{t} / \mathrm{ha}$, grown in New Zealand (https://tinyurl.com/y44xpsgr). We know what that crop looked like above ground, but surprisingly little of what it looked like below ground. Modelling (Lilley and Kirkegaard 2011) and experimental work (Severini et al. 2020) have shown that deeper, more dense root systems are correlated with high yields under optimal growing conditions.

\section{Climate change and yield 'resiliency'}

Alongside yield potential, yield resilience/stability across a range of environmental conditions is also necessary to minimize seasonal volatility in production and grain quality (Nuttall et al. 2017), especially as growing conditions are becoming less predictable under climate change (Powell et al. 2012; Mickelbart et al. 2015; Scher and Messori 2019). Because crossover behaviour is common, there is no guarantee that a genotype with high yield in the absence of limitations in water or nutrients would also perform well in low input, stressed or marginal environments (Bustos-Korts et al. 2019). Nevertheless, it has been shown that conventional breeding selection has identified high yielding material adapted to poorer conditions by starting with germplasm with good yield potential (Voss-Fels et al. 2019). It is important to understand which RSA works best in which agricultural context, or at least to provide breeders with a range of RSA types to select empirically which is most successful in different target environments, and in the context of different germplasm pools with varying component trait configurations (e.g. Messina et al. 2011). Climate change presents an additional challenge to breeders (Zampieri et al. 2017). In the past, by selecting for yield in each cycle breeders could improve adaptation to local environments, effectively keeping pace with gradual changes in climate. With the current rate of change (and increase in variability) in climate, a key question is whether current breeding practices will continue to be able to deliver the required rate of genetic progress? Perhaps it is too risky to wait to find out, as the development time from initial cross to released wheat variety is approximately 8 years.

At the outset it is valuable to have a clear view of what 'climate resilience' means in order to understand what features of a root system would best support a 'resilient' crop. In addition to increased air temperatures and incidence of heat stress, climate change models also predict changes in rainfall patterns, with an increase in severity and frequency of drought in some regions, and increased probability of flooding in others (Gornall et al. 2010; Hammer et al. 2020). A 'resilient' crop should minimize the potential losses in yield when these conditions prevail. A number of root traits could be important, depending on the environment. During drought, when surface soil layers have been depleted of moisture, root systems that extend deeper into the soil profile may be able to access water (provided that subsoils are replenished by seasonal rainfall), which can help sustain transpiration and photosynthetic rates. In other environments where rainfall is limited and sporadic, the presence of roots in superficial soil layers that remain viable and able to capture water from intermittent rainfall may be advantageous.

The global rise in temperatures may have a smaller direct effect on roots than shoots, as soil temperatures at depth are buffered against fluctuations in air temperatures (Kätterer and Andrén 2009), but some evidence suggests that RSA is sensitive to changes in soil temperature (Luo et al. 2020). Many genes responsive to temperature have pleiotropic effects on both shoot and root traits (e.g. Voss-Fels et al. 2018). Heat stress effects on shoots can be ameliorated in part by maintaining evaporative cooling of the plant through transpiration, and here root systems play an important role (Lopes and Reynolds 2010). During periodic flooding, roots with increased ability to form aerenchyma would confer an advantage, and such 'cheaper' roots that have less cortical cell burden per unit length and therefore less metabolic costs can also be beneficial in dry conditions (Chimungu et al. 2019; Klein et al. 2020). Climate change will likely alter the profile of root pest and disease pressures (Juroszek and von Tiedemann 2013), so incorporation of durable sources of resistance represents another form of resilience. A 'resilient' variety is one with traits that confer a better likelihood of performing well given the stochastic nature of local weather conditions that define a particular growing environment. We argue that breeders no longer need to consider root systems as a 'one size fits all' component and hope for the best. Rather, by introducing RSA ideotypes with specific morpho-physiological traits now into breeding pipelines should improve climate resilience at a faster pace than random occurrence of advantageous RSA. In this review we present the case for tailoring root systems by incorporating more than one component RSA trait at a time (e.g. Fig. 1), outline the tools breeders need to bring about these improvements and provide some examples where progress is happening.

\section{A tailored root system: the traits that define root architecture and their potential use for improved crop performance}

Unlike the 'taproot' system of dicotyledonous plants (in which the primary root forms the main root with branching forming secondary, lateral roots and root hairs), monocots such as wheat have root systems comprised of a wide network of finer roots. These consist mostly of nodal roots that arise from the stem nodes, in addition to the seminal 
roots, lateral roots and root hairs (Hochholdinger et al. 2004) (Fig. 1). Due to research efforts over more than 150 years, we understand quite a lot about how roots grow and develop. From description of root tropisms by Darwin, to field excavations of entire root systems by Weaver in the 1920s (Rich and Watt, 2013), through to cloning genes controlling root development and cell fate (Motte et al. 2019), the published information on roots is extensive. Darwin's fascination with the root tip was well placed, because the complex signalling that occurs between the root apex and the cells within the root growth zone, plus signals from plant tissues distal to the growth zone, all determines the growth trajectory of the nascent root, and therefore the establishment of the final architecture of the root system fixed in place in the soil. The initiation of root growth through production of root primordia, and the number and spatial arrangement of new root tips are also critical to formation of RSA. Crop plants such as wheat have embryonically formed primary and seminal axile roots and post-embryonically formed, nodal axile roots (for more information on wheat root nomenclature, see Watt et al. 2008). Seminal and nodal axile roots form up to three levels of branch roots, with at least five types of anatomical arrangements. Modification of RSA is strongly affected by root branching (Osmont et al. 2007); branches comprise most of the root length after the four-leaf developmental stage of wheat (Watt et al. 2008). Hydrotropism is the ability of roots to initiate lateral root primordia localized to available water (Bao et al. 2014) and to grow new main roots after a rewetting event (Sebastian et al. 2016). This increases the plant's plastic response to water shortages and therefore increases resource efficiency by only growing roots where and when they can be useful for water and nutrient uptake (Comas et al. 2013). Hard soils with high penetration resistance present another challenge to roots in many field situations. This can result from mechanical compaction or the increase in soil strength that accompanies soil drying (Whalley et al. 2008). In these problem soils, a genotype with a deep-rooted RSA may not be able to express that phenotype. Therefore, the ability of roots to penetrate hard soils, or more likely, to 'find' the cracks, pores and fissures in and between soil peds is an important characteristic of root growth in some environments (Atkinson et al. 2019a, b). It is conceivable that genotypic variation may exist in the oscillatory movement of root tips that is important for this type of soil exploration (Taylor et al. 2020), and perhaps this could be exploited through breeding.

Much of the cereal root system is composed of fine (or lateral) roots and the entire root system is covered with root hairs (Nestler et al. 2016a, b). The rhizosheath, the soil-polysaccharide complex that adheres to roots, relies on mucilage secretion and the presence of root hairs, which enmesh soil particles (Watt et al. 1994; George et al. 2014). Longer root hairs favour larger rhizosheath formation, which also depends on soil water content (Haling et al. 2014) and root type (Nestler et al. 2016a, b). Rhizosheath characteristics may impact plant performance, such as enhancing drought tolerance due to the mucilage water-holding capacity, which attenuates the decline in rhizosphere hydraulic conductivity that occurs during soil drying (Zickenrott et al. 2016).

Compounds released by roots account for $5-40 \%$ of total carbon fixed by the plant (Whipps and Lynch 1983; Badri and Vivanco 2009), thus it is likely that root secretions confer a significant benefit, perhaps by allowing plants to tailor the root microbiome to their advantage. There is evidence that rhizosphere microbes can contribute to the uptake of minerals (Bais et al. 2006), tolerance to drought (Kim et al. 2012) and salinity (Zhang et al. 2008; Fatima et al. 2019). Rhizosphere dynamics are complex (McCully 1999) and microbial communities change in response to many factors, including host plant genetics (Aira et al. 2010; Schmidt et al. 2016; Yu and Hochholdinger 2018). Thus, it is conceivable that as we gain more understanding of these factors, varieties can be bred to support a managed microbiome that improves resilience of the crop.

The list of root traits highlighted above is by no means comprehensive, and there is a plethora of phenotypes that could confer advantages to crop performance in different growing conditions, many of which have been reviewed elsewhere (e.g. Tracy et al. 2020). Here we consider two broadly defined traits in more detail, due to focus on these phenotypes in recent wheat research: root angle and root biomass. These can be considered 'coarse' traits as the phenotype has several layers of expression, so requiring careful definition. To determine root angle, root initials grow along a certain vector in relation to gravity, according to the gravitropic setpoint angle (GSA; Roychoudhry et al. 2017). Growth continues along this trajectory set by the GSA, such that root tissue is established at a fixed angle to vertical. The GSA may change as the root matures or as the root tip responds to local stimuli it encounters in the rhizosphere. Although it is well known that the GSA is set by auxin gradients within the root tip (Toal et al. 2018; Overoorde et al. 2010; Waite et al. 2020), the number of genes and their function in the network regulating this gradient are less well characterized. Two desirable features of root angle at the seedling stage make it particularly suited for genetic studies: the limited effort needed for its measurement in the large numbers of lines that are needed for genetic analysis and its high heritability (Sanguineti et al. 2007; Canè et al. 2014). Notably, a significant correlation has been reported between seminal root angle at the seedling stage and crown root angle measured at maturity in the field (Maccaferri et al. 2016; Alahmad et al. 2019), and as illustrated in Fig. 2. This finding is important because seedling assays are typically conducted on individual plants grown in isolation from other plants, whereas in the field, individuals are members of a 

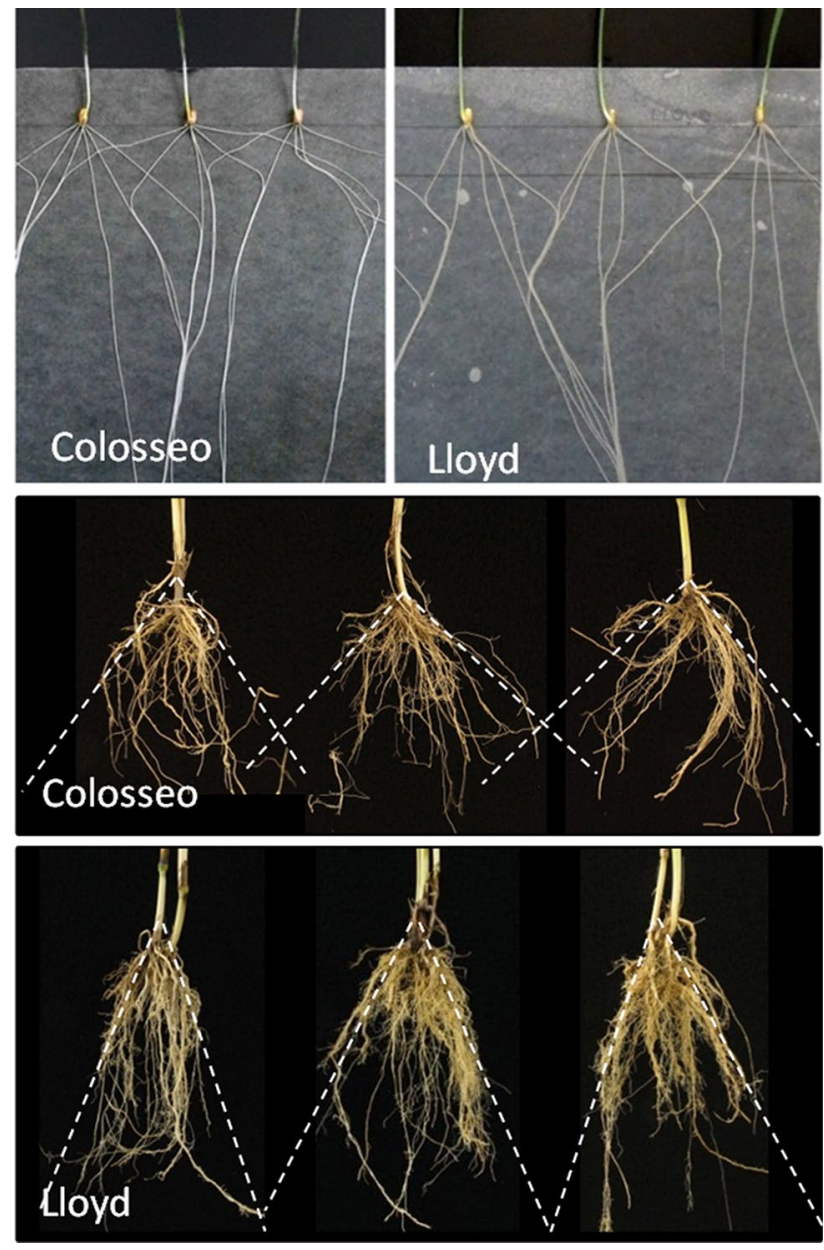

Fig. 2 Correlations between seedling stage and adult plant root phenotypes for the founders of a bi-parental durum wheat mapping population. Top panel: Seminal root system grown on germination paper. Middle panel: wide crown root angle in cv. Colosseo from fieldexcavated plants. Bottom panel: narrow crown root angle in cv. Lloyd from field-excavated plants

population where roots interact with those from neighbouring plants (and sometimes weeds). Indeed, spacings between plants within and between rows can affect RSA (Hecht et al. 2019). Roots with a narrow GSA (i.e. where root tips respond strongly to gravity and so grow closer to vertical) generally result in an overall root system that places more root biomass in deeper soil layers, compared with a root system with a wider GSA that has a greater distribution in the upper soil layers (Alahmad et al. 2019; Lynch 2013; Oyanagi et al. 1993). A deeper root system allows greater access to soil moisture during water deficit, at least in environments that allow replenishment of water in deeper soil layers by seasonal rainfall. Plants with more root biomass at depth could be better at capturing soluble nitrogen before it leaches into groundwater. For example, studies of wheat lines with the chromosome 1RS.1BL translocation from rye show the introgression is associated with greater root biomass at depth and smaller nitrate concentration in leachate than the parent line that lacks the translocation event (Ehdaie et al. 2010). Yield advantages for deeper roots in the field have been demonstrated in bread wheat (Lopes and Reynolds 2010; Li et al. 2019a, b) and durum wheat (Maccaferri et al. 2016; El Hassouni et al. 2018), as well as in rice (Uga et al. 2013), barley (Robinson et al. 2018), triticale (Severini et al. 2020), maize (Gao et al. 2016; van Oosterom et al. 2016) and sorghum (Mace et al. 2012). The fundamental question of whether there is a link between root angle and depth under field conditions has not yet been answered for wheat. Additionally, more complex questions remain, such as how root angle and root biomass interact to promote water acquisition under different soil water availability scenarios, how root biomass and angle relate to above-ground plant architecture in terms of biomass partitioning, and how root traits interact with other above-ground physiological traits.

\section{Phenotyping methods for characterization and exploitation of root system architecture}

To improve a trait in new varieties, including root systems, breeders typically need three fundamental inputs: (1) donor germplasm that contain favourable alleles for the target trait, (2) a way to identify the trait, either by appearance (phenotypic selection) or by the presence of a particular allele (marker-assisted selection) and (3) the human and capital resources to implement the process of selection and breeding. The decision on how much resource to commit to a trait partly depends on whether the value it brings to the final product pays for the effort (and compensates any yield penalties that may come with it). Therefore, the tools and the evidence need to be in place to allow breeders to get such improvements into the hands of farmers.

To best explore the opportunities for the targeted design and selection for RSA traits, appropriate phenotyping methods must be used. Given the complex nature of roots and the difficulties in accessing them when grown in soil, the choice of phenotyping methodology should consider both the root trait to be targeted, and the growth system under which the roots are to be assessed. For example, phenotyping root systems of young plants has practical advantages, as plants can be screened under controlled environment conditions for short periods of time, from two days to a few weeks, so allowing larger numbers of plants to be screened. While controlled conditions typically lead to more reproducible phenotypic results (Poorter et al. 2016), seedling root growth does not always correlate well with mature plants or plants grown in the field (e.g. Bai et al. 2019). The strength of young plant traits as predictors of traits in mature plants depends on many factors, such as the underlying genetic factors, genetic background of the test materials, phenotyping 
methods and nature of the test environments. Therefore, compromises between complexity of the experimental system and the reliability and reproducibility of the resulting phenotypes must be found. In a breeding context, the choice of the phenotyping strategy would also be affected by the stage of the breeding programme (e.g. line development versus yield testing phase). Keeping these considerations in mind, here we give a brief summary of the methods commonly used to investigate RSA.

\section{Small plant approaches: from filter paper and agar to rhizotrons}

Non-invasive, time-resolved observations of roots are possible when growing seedlings in transparent pots (e.g. Richard et al. 2015) (Fig. 3a), on germination paper (e.g. Gioia et al. 2017) (Fig. 3b), agar plates (Nagel et al. 2020), or in paper or cloth pouches (Shorinola et al. 2019; Chen et al. 2020). While some of these growing platforms require sterile conditions and manifestation of the desired trait within two to three weeks, they enable relatively high throughputs of several hundred plants at a time. Alternatively, plants can be efficiently screened for RSA traits in soil-filled glass-walled 'rhizotrons' (Fig. 3c), where root growth can be monitored over time (e.g. Nagel et al. 2012; Jeudy et al. 2016). Using rhizotrons to investigate young plants before their roots reach the constraints of the containers (Passioura 2006; Sinclair et al. 2017) allows tracking of natural root system growth in (2D) space and time, or mapping more mature root systems in 3D (Topp et al. 2013). In large rhizotrons, it is possible to observe and measure roots to $4 \mathrm{~m}$ depth, but these are not suitable for comparing large numbers of genotypes (Svane et al. 2019). In general, rhizotrons require more space than the paper or agar methodologies described above. However, medium-to-high-throughput rhizotron facilities are currently available at the Forschungszentrum Jülich and Leibniz Institute-IPK, capable of screening hundreds of wheat plants in a single experiment (Fig. 3c).

\section{Field-based root phenotyping}

Root phenotyping in the field is often considered more complex, time-consuming and labour-intensive than seedling approaches. In the method commonly termed 'shovelomics', large numbers of root crowns are excavated either using a shovel or manually, depending on the soil conditions (Fig. 3d). This approach is surprisingly fast, with throughput of up to $\sim 50$ shovel excavations/h/person. However, it is an invasive method and it only allows access to roots growing in the top $20 \mathrm{~cm}$ of soil. Nevertheless, when combined with image analysis, shovelomics can provide useful insights into traits such as nodal root number or growth angle of fieldgrown crops, including wheat (Maccaferri et al. 2016; York et al. 2018; Fradgley et al. 2020). A non-destructive technique for observing field-grown roots over time is also possible by employing 'minirhizotrons' - transparent cylinders that are placed into a field in a desired position before planting, either with an installed camera for continuous imaging, or with an opening to insert e.g. an endoscope for root imaging at a specific time point. Minirhizotrons give insights into root number and length over time, but they are limited to pre-defined positions (Crocker et al. 2003). Assessing root structure in the field at greater soil depths can be undertaken using soil coring, typically using a tractor-mounted hydraulic system (Wasson et al. 2016), followed by core breaking (Fig. 3e, f), washing and root measurement. A new approach to the phenotyping of soil cores involves core breaking and counting of roots at the core face without washing. Soil coring is more time intensive ( $<5$ cores/h/person) and costly than shovelomics, requiring specialized equipment (Wasson et al. 2016). However, the data obtained are roots per soil volume, potentially to a depth of $2 \mathrm{~m}$, making them useful for crop growth models that require a root length density at each soil layer. To increase throughput, Wasson et al. (2016) recently developed a method for automated detection of roots at the core break interface via image analysis and UV (365 nm) LED illumination that increases the contrast between the roots and the soil.

\section{Remote sensing for indirect root phenotyping}

The throughput of direct observation of root systems in the field is currently insufficient for routine application in breeding pipelines. An alternative approach is to use remote sensing methods to phenotype above-ground traits as a proxy for below-ground traits. Remote sensing has been used to estimate soil water availability, relative root depth and root/ shoot ratio at the genotype level. For example, a direct phenotypic and genetic link has been found between wheat root mass and canopy temperature under both drought and hot/ irrigated conditions (Lopes and Reynolds 2010; Pinto et al. 2010). Subsequent root excavation work showed that the lines with cooler canopies (and the associated genetic loci associated with this trait) express a larger root mass under both drought and heat, though with different root distribution profiles, reflecting where water was available to roots under the distinct environments (Pinto and Reynolds 2015; Li et al. 2019a, b). Parallel work investigating the spectral reflectance 'water index' showed its sensitivity to genotypic effects on both leaf and soil water potential in drying soils (Gutierrez et al. 2010), the latter being a direct function of water uptake by roots. Since canopy evapotranspiration is a function of root access to water and the demand created by the leaf canopy and atmosphere energetics, canopy temperature and water index signals likely predict relative root capacity (i.e. root/shoot ratio) rather than root mass per se. Normally, 

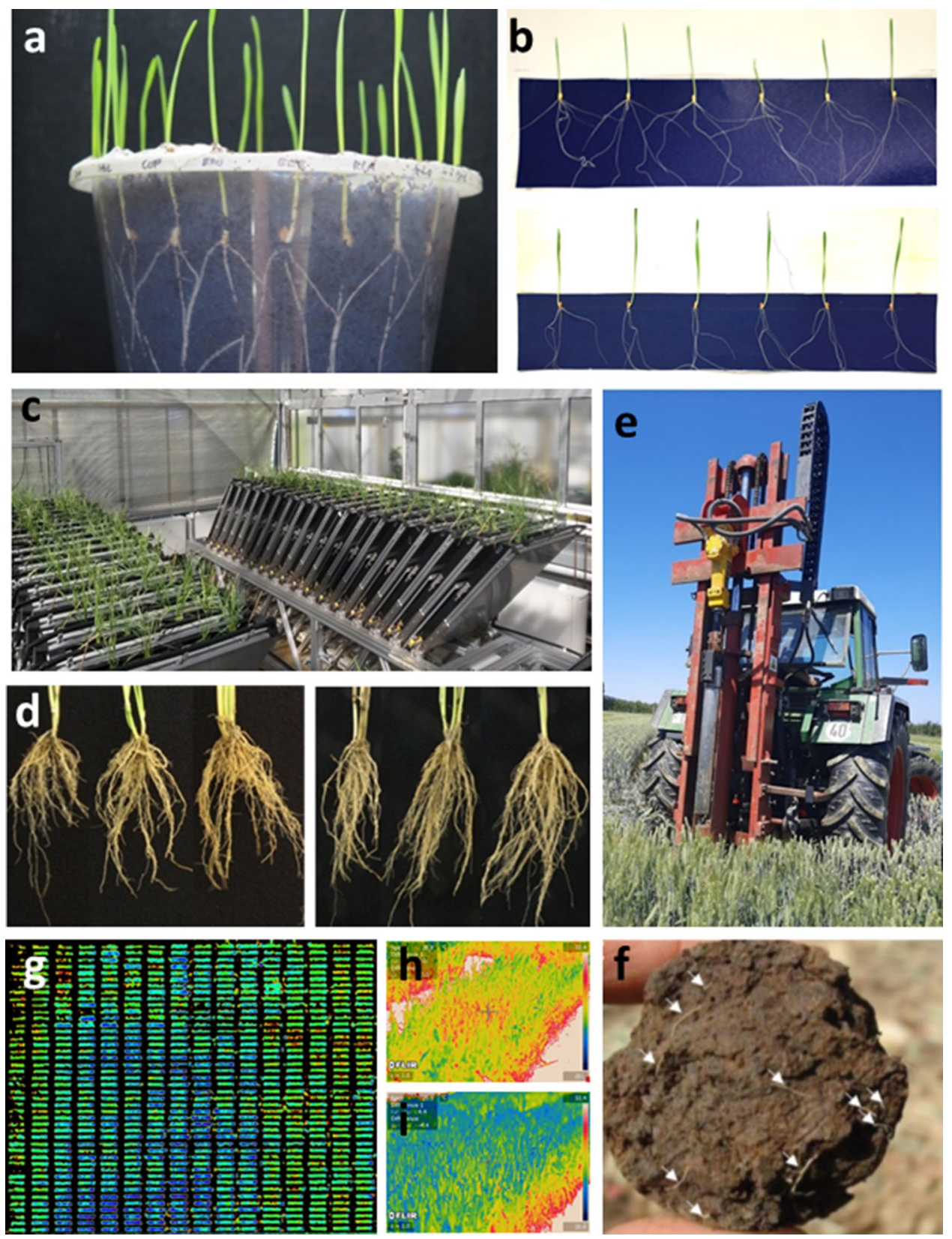

Fig. 3 Examples of wheat root phenotyping methods. a The "clear pot' seedling method (Richard et al. 2015). b Germination paper method, with the upper and lower panels illustrating seedlings with wide and narrow seminal root angle, respectively. c Rhizotrons at the Forschungszentrum Jülich. d Root crowns excavated from the field (e.g. York et al. 2018). e Field-based soil coring via a tractormounted rig, with $\mathbf{f}$ a view of a broken soil core allowing roots to be counted (arrows) (from Wasson et al. 2016). g A false-colour orthomosaic thermal image of a field trial of a wheat mapping population (HiBAP2Y18_2H), planted at the CIMMYT field station in Obregón, Mexico. Images were captured using a thermal camera mounted on a UAV (Zenmuse XT, DJI). Cooler canopy temperatures are blue, and

canopy temperature is predominantly driven by evaporative cooling of the leaf surface via transpiration, which is a function of feedback control loops between stomatal conductance warmer temperatures are red. Averaging pure pixel values produces a numerical value for canopy temperature for each genotype and plot $(0.8 \mathrm{~m} \times 4 \mathrm{~m})$. Previous studies have shown that canopy temperatures are related to transpiration rates and soil water extraction by the root system (see text). The image also shows spatial variation across the trial site and variation within the plot, which have to be taken into account to increase the heritability of the temperature trait values. Close-up images of plots made with a hand-held thermal camera taken within a few minutes of each other, showing contrasts between genotypes in neighbouring plots within the same trial in the UK: $\mathbf{h} \mathrm{cv}$. Apache, i cv. Paragon (color figure online)

and plant hydraulic conductivity, controlled in part by root vascular capacity. However, as the soil dries or evaporative demand increases, canopy temperature is increasingly 
determined by the capacity of root systems to supply water for transpiration. Thus, canopy temperature and water index signals become progressively more sensitive to genetic differences in root capacity as soil water becomes limiting. The development of such a root index (based on modelling of remote sensing data under well-defined environmental conditions) would have profound implications for our ability to rapidly screen root capacity at a breeding scale. In large field trials, spatial and temporal variation in canopy temperatures can be minimized via rapid imaging using thermal cameras mounted on drones or piloted aircraft (Deery et al. 2019; Fig. 3g).

Additionally, non-invasive methods based on geophysical techniques are being developed, such as ground penetrating radar (GPR). GPR uses high-frequency radio waves to detect roots by exploiting differences in electromagnetic properties between roots and the soil and has been used to estimate growth of storage roots in cassava (Delgado et al. 2017). Though typically more successful when applied to larger ( $>1 \mathrm{~cm}$ diameter) roots, GPR has been shown to predict bulk root biomass and diameter in winter wheat (Liu et al. 2018). Finally, living root biomass distribution can be estimated by indirect measures of root activity, such as water uptake. Wheat genotypic differences in water uptake in deep soil layers have been demonstrated using a frequency domain reflectometry type soil moisture sensor (Ober et al. 2014), although this method also requires installation of soil access tubes in the field. Electrical resistance tomography (ERT) and electromagnetic inductance (EMI), which are commonly used to map soils at different depths, have been used to quantify changes in apparent conductivity related to soil moisture content, and thus to discriminate soil drying profiles of different genotypes in the field (Whalley et al. 2017).

\section{Emerging developments in root phenotyping}

Among the emerging trends in root phenotyping are improvements in non-destructive methods for controlled environments (Atkinson et al. 2019a, b) and direct, deep phenotyping under field conditions (Wasson et al. 2020). Contemporary root phenotyping platforms under controlled conditions now routinely co-image both shoots and roots, greatly speeding up the introgression of desirable shoot and root phenotypes (Tracy et al. 2020). Although they require specialist equipment and facilities, magnetic resonance imaging and micro-X-ray computed tomography allow nondestructive, time series 3D imaging of RSA and rhizosphere properties in fine detail (Mairhofer et al. 2012). Improvements in scan times and use of robotics has increased sample throughput (Tracy et al. 2020). For selection of root anatomical traits at the cellular level such as aerenchyma, laser ablation tomography has increased throughput compared with conventional microscopic techniques (GalindoCastañeda et al. 2018).

\section{The genetics and genes controlling RSA}

Wheat, along with the related grass crop species rice and maize, represent the three most important staple crops globally. Our current understanding of the genes controlling root traits in wheat is relatively sparse. Therefore, here we first give a brief overview of the current knowledge in maize and the model grass species, rice.

\section{Model roots: cloned RSA genes in rice and maize}

At least eight maize genes controlling root system architecture have been identified to date (recently reviewed by Hochholdinger et al. 2018). Of these, key elements of seminal, shootborne and lateral root development are controlled by genes in the auxin signalling pathway: rootless with undetectable meristem1 (ruml), rtcs, rtcs-like (von Behrens et al. 2011; Taramino et al. 2007; Xu et al. 2015). In contrast, genes controlling root hair formation have been found to regulate the properties or synthesis of cellulose and the cell wall (roothairless3 (rth3), rth5 and rth6) (Hochholdinger et al. 2008; Nestler et al. 2014; Li et al. 2016) or exocytotic vesicle docking (rthl, big embryol) (Wen et al. 2005; Suzuki et al. 2015). Notably, two major QTL controlling the number of seminal roots in maize co-map with the root developmental genes rtcs and ruml (Salvi et al. 2016), hence supporting the hypothesis that mutants and QTL are underpinned by the same loci but with much stronger additive effect in the former compared with the latter (Robertson 1985; Bohn et al. 2006). Genes controlling RSA have also begun to be characterized in rice (reviewed by Meng et al. 2019), with two root trait QTL having been map-based cloned to date. The first was the genetic locus DEEPER ROOTING 1 (DRO1), found to be encoded by a protein with two putative $\mathrm{N}$-myristoylation sites associated with lipid modification (Uga et al. 2013). DROI influences seedling root angle via modulating gravitropic response, with the deep rooting allele found to improve grain yield under field drought stress (Uga et al. 2013; Arai-Sanoh et al. 2014). More recently, the rice QTL $q R T 9$ controlling root thickness and length was found to encode the basic helix-loop-helix transcription factor, OsbHLH120 (Li et al. 2015). OsbHLH12O expression was induced by application of various conditions in hydroponic culture $(\mathrm{NaCl}$, polyethylene glycol and abscisic acid); the observation that this response was stronger in plants carrying the long/thick root allele indicates that selection for this allele provides an opportunity for breeding drought tolerant lowland rice varieties. 


\section{Genetic control of RSA in wheat}

In wheat, little is known about the underlying genes controlling root architecture. Aside from the complexities in root phenotyping, this is likely due to the large, highly repetitive and polyploid nature of the wheat genome (17 Gbp for hexaploid bread wheat, approximately 40 times that of rice) as well as the buffering effects of homoeologous genes present within its three sub-genomes (Borrill et al. 2019). Indeed, although many hundreds of RSA QTL have been identified (e.g. as summarized in the meta-analysis conducted by Soriano and Alvaro 2019), only two genes controlling RSA in wheat have been formally identified. The first is VERNALIZATION 1 (VRNI), which influences root angle at all stages of plant growth (Voss-Fels et al. 2018). Interestingly, natural variation at $V R N 1$ has long been recognized as a major-effect gene controlling the transition from vegetative to reproductive growth in wheat (Yan et al. 2003; Cockram et al. 2007). That such a well-studied gene has only recently been shown to be involved in root system architecture perhaps highlights the comparative lack of research resources wheat root traits have previously been afforded. More recently, the barley root angle mutant enhanced gravitropism 2 (egt2) encoding a STERILE ALPHA MOTIF domain-containing protein has been cloned, which results in narrower and lateral root growth angle compared to wild-type, combined with higher response to gravity in an auxin-independent manner (Kirschner et al. 2021). Combining mutations in the A and $\mathrm{B}$ genome copies of the orthologous gene in tetraploid wheat resulted in narrower seminal root growth angle, indicating EGT2 could be a target for root-based cereal crop improvement (Kirschner et al. 2021).

Novel approaches for wheat speed breeding (Watson et al. 2018) and root phenotyping are now converging with the coming of age of wheat genomics resources (reviewed by Adamski et al. 2020). Applied together this can accelerate generation of novel germplasm to test RSA ideotypes in the field. The publication of the fully annotated reference wheat genome assembly in 2018 (IWGSC 2018) has been rapidly followed by the release of 15 additional assemblies of modern bread wheat cultivars (Walkowiak et al. 2020). Together with gene expression databases (Ramírez-González et al. 2018), this allows more rapid discovery and characterization of genes controlling RSA in wheat. For example, forward phenotypic identification of induced mutants affecting root traits similar to that initiated in maize in the 1990s (e.g. Wen et al. 1994; Hochholdinger and Felix, 1998) are now being undertaken in wheat, identifying for example seminal root number mutants at the seedling stage (Shorinola et al. 2019). As these artificially mutated wheat germplasm resources have also been sequenced (Krasileva et al. 2017), reverse genetics approaches focusing on wheat orthologues of genes known to affect RSA in other cereals, such as wheat orthologues of DROI (Ashraf et al. 2019), can also be rapidly identified for subsequent characterization. Translational genomics from model plants such as Arabidopsis, which exploits the conservation of gene sequence and function across species, has led to the discovery of novel genes in wheat that control primary root growth and morphology, such as TaARF4 (Wang et al. 2019) and TaLAMP1 (Shi and Tong 2020). Similarly, the recent development of genotyping platforms (e.g. Allen et al. 2017) that can rapidly type genetic variants throughout the wheat genome is contributing to the availability of increasingly finely mapped wheat RSA QTLs. Indeed, numerous QTL mapping studies have dissected the genetic control of root traits, with the majority of these involving bi-parental populations (e.g. Maccaferri et al. 2016). These advances in genomic resources should facilitate identification of haplotypes or alleles that can be used to alter RSA in wheat in a targeted manner. A notable example is the identification of a major locus controlling $>50 \%$ of the phenotypic variance for primary root length on bread wheat chromosome 2B (Ren et al. 2012), with subsequent proteomics investigation implicating the role of transforming growth factor (TGF)-beta receptorinteracting protein-1 (TaTRIP1) in the control of meristem size (He et al. 2014).

Recently, the use of other population types for genetic analysis has become increasingly common in crops (reviewed by Cockram and Mackay 2018). For wheat root traits, these include the use of genome wide association studies (GWAS) on nested association mapping (NAM) populations and association mapping panels consisting of large collections of varieties or accessions. One of the advantages of these techniques is the possibility to evaluate more than two haplotypes at any given locus, thus allowing a wider range of genetic diversity to be explored. A good example of the potential of these approaches is the investigation of a major genetic locus on chromosome $6 \mathrm{~A}$ of durum wheat controlling root angle. First identified by GWAS of seminal root phenotype in elite germplasm (Sanguineti et al. 2007; Canè et al. 2014), and subsequently validated on the whole root system under field conditions (Maccaferri et al. 2016; Fig. 2), the effect of this QTL on root angle and agronomic performance was further validated in a durum NAM population (Alahmad et al. 2019, 2020) and via GWAS conducted with Ethiopian durum accessions (Alemu et al. 2021). A recent use of GWAS for analysis of root traits in bread wheat is reported by Voss-Fels et al. (2017), who identified two epistatic loci on chromosome 5B controlling root biomass. Interestingly, the high-biomass allele combination at these loci was found to be absent in elite European germplasm.

In addition to the genetic diversity present in elite germplasm, natural variation present in landraces and related cereal species represents a reservoir of potentially novel alleles that is now beginning to be exploited in the context 
of RSA traits. For example, assessing a near isogenic line (NIL) pair differing for the introgression of a region of chromosome 7A from wild emmer wheat (T. durum subsp. dicoccoides) into an elite durum wheat cultivar found the introgression to confer higher yield under drought conditions (Merchuk-Ovnat et al. 2016). This was underpinned by a significant and consistent effect of the wild emmer introgression on RSA (Merchuk-Ovnat et al. 2017). Another example of the beneficial effect of chromosomal introgressions on RSA is the chromosome 1RS.1BL translocation from rye (Secale cereale L.) into bread wheat, which affects grain yield and canopy water status (Villareal et al. 1991; Howell et al. 2014). The introgression has since been found to affect RSA traits by maintaining root apical meristem activity over longer time periods, resulting in longer axial roots and improved deep-water capture (Ehdaie et al. 2003; Howell et al. 2019). Conversely, the wild-type bread wheat allele reduced the meristematic activity of the seminal root apex 10 days after germination, resulting in reduced seminal root length and lateral root proliferation. The importance of the lateral/axial root meristematic activity balance in wheat root deepening has also been highlighted in another study involving an alien introgression into bread wheat, in which a translocation from the wheat wild relative Agropyron elongatum on chromosome 7D caused impaired lateral root proliferation as a consequence of water deficit, resulting in the maintenance of meristematic activity of axial root apexes (Placido et al. 2013). Chromosomally engineered durum wheat Thinopyrum ponticum recombinant lines tested in a range of contrasting rain-fed environments showed associated effects between seminal root angle and yield (Kuzmanović et al. 2018). By exploring root gene transcription in lines contrasting for this introgression, as well as RNAi gene silencing in bread wheat, the gene LATERAL ROOT DENSITY (LRD) was identified as a repressor of root growth under drought conditions and was proposed to control the deeper rooting phenotype under drought conditions conferred by the Agropyron introgression (Placido et al. 2020).

Researchers in the pre-breeding community have focused on studying diversity panels and bi-parental mapping populations to discover root trait QTL, but have faced challenges when it comes to precisely quantifying the value of specific root traits. While these populations segregate for root traits, most also segregate for above-ground developmental traits that have a major impact on the timing of water-use and carbon partitioning, for example flowering time and plant height. Therefore, the ability to determine the value of different root traits and their contribution to yield is confounded by above-ground variation. We propose that development of elite introgression lines for target root traits with similar above-ground behaviour would provide valuable materials for evaluating the value of the new trait in different environments or production scenarios (Fig. 4). We further propose that, given the availability of new genomics tools, advances in crop models/genetic simulations, low-cost and efficient phenotypic screening systems and speed breeding technology, this targeted approach to validate root trait QTLs and trait value could help accelerate progress in wheat.

\section{Genetic engineering and gene editing for precise modulation of RSA in elite wheat germplasm}

There are currently few examples of RSA trait introduction into wheat through genetic engineering, due predominantly to the relatively recent establishment of the necessary methodologies and underpinning genomic resources in wheat. Examples include increased wheat root hair development mediated by TaRSL4-A expression, as well as expression of the flowering regulator, VRNI used to confirm the role of this gene on modulating RSA in both wheat and barley (Han et al. 2015; Voss-Fels et al. 2018). Recent improvements in wheat transformation methods (Debernardi et al. 2020) and the development of new breeding technologies utilizing site-specific nucleases such as zinc finger nucleases, TALENS and CRISPR (Zhu et al. 2020), meaning that precise modification of DNA sequences in elite wheat varieties is now possible. Individual genes, or gene families can be precisely targeted by the nuclease to abolish gene function (GilHumanes et al. 2017; Li et al. 2018). The use of ribonucleoprotein complexes to deliver editing components removes the need for foreign DNA to be stably integrated and segregated away so that GM regulation may not be required (Liang et al. 2017). Coupled with availability of a donor template, the less efficient homology-directed recombination pathway can precisely introduce new alleles, creating a desired haplotype without the need for an extensive crossing programme (Shi et al. 2017). As genome editing methodologies have rapidly advanced, modification of the temporal and spatial expression of target genes has now become possible (Lee et al. 2019, Gallego-Bartolomé 2020). These modifications could have profound implications for the future validation and exploitation of genes underlying RSA QTL without associated linkage drag from closely linked alleles. Recent examples include CRISPR editing of the cotton GhARG gene which resulted in increased lateral root formation and, in barley, knockout mutation of the $H \nu C K X I$ gene resulted in greater root length and increased surface area (Wang et al. 2017; Gasparis et al. 2019). While no known RSA genes have been modified in wheat to date, and the generation of full gene-edited knockouts in polyploid crops has proven challenging, recent strategies to improve editing in hexaploid wheat make this a realistic prospect in the near future (Milner et al. 2020). Several countries currently regulate these gene-edited crops as genetically modified events-even if the foreign T-DNA has been removed, leaving just the gene edit. However, the use of ribonucleoprotein complexes or 


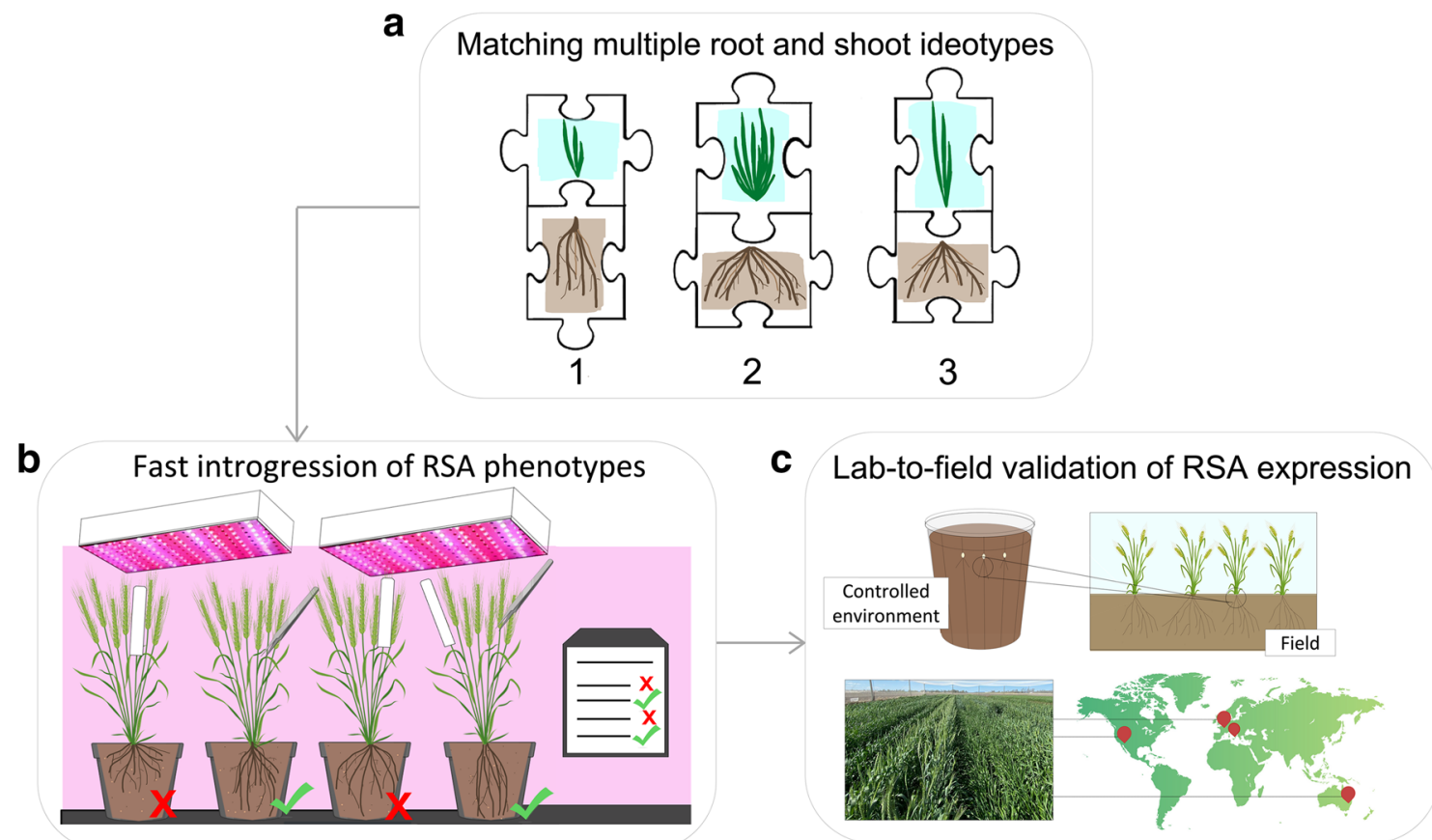

Fig. 4 An approach for matching and evaluating multiple root and shoot ideotypes in elite wheat genetic backgrounds adapted to different growing regions. a Genetic loci identified as controlling root traits and shoot traits are used as the starting points for $\mathbf{b}$ back-crossing into elite wheat varieties. 'Speed-breeding' growth conditions (Watson et al. 2018), combined with clear-pot root phenotyping (Richard et al. 2015) and marker-assisted selection (Makhoul et al. 2020), allow

haploid induction systems (Kelliher et al. 2019) to deliver the editing components removes the need for foreign DNA to be stably integrated and segregated away. This approach has been demonstrated in wheat, opening the door for geneedited wheat that falls outside the scope of current GM regulation (Liang et al. 2017).

\section{The missing piece of the puzzle: root plasticity}

RSA traits are governed not only by genetics but also by environmental conditions, such as soil structure, moisture, nutrient availability, temperature and biotic factors. Quantitative traits such as root angle are controlled by multiple genes, and a systems approach is required to understand how that gene network is regulated, including those elements that respond to environmental signals (Rellán-Álvarez et al. 2016). Thus, within the root system of a plant, or a specific component of that root system, multiple states are possible depending on the local transcriptional, translational and post-translational status of each gene and its interaction within the network, resulting the development of near isogenic lines (NILs) that combine multiple above- and below-ground traits into elite wheat varieties adapted to different agricultural environments. $\mathbf{c}$ The targeted root and shoot traits can then be validated in the NIL materials under both controlled and field environments to determine their effects on overall crop performance

in a plastic expression of the phenotype (which perhaps can be more accurately viewed as an environment-specific trait response). For example, Schneider et al. (2020) showed that in maize, the genes controlling root anatomical traits under different water regimes or locations could be differentiated from sets of genes that were associated with the plasticity of the traits (the proportional change in expression across environments). It remains unclear what aspects of plasticity are maladaptive, neutral or beneficial for productivity. For those traits that show plasticity such as root angle, the targets for breeding would include not only those major-effect genes that establish the setpoint angle, but also those genes that modify the setpoint in response to an environmental signal such as water deficit (Schneider and Lynch 2020). Dynamic developmental root traits such as root growth rate, which must be determined from measurements at more than one time point, may also be important features of plastic responses. Exploiting genetic variability for the regulation of root growth rate (Li et al. 2019a, b) may be one route to increased climate resiliency. For certain target environments, breeders may opt for less plasticity via a combination of alleles that maintain a network status that shows low responsiveness to environmental signals; e.g. consistent maintenance of 
narrow root angle for conditions where resources are low in the upper soil layers. In other situations, greater plasticity may confer yield advantages, which would be desirable despite low heritabilities for those traits. Such decisions will need to be based on extensive experimental data on genotype, root phenotype and yield and a greater understanding of how those gene networks function.

\section{Outlook for breeding better wheat root systems}

We view the critical steps to underpin future direct selection of root traits for improved crop performance as being: (1) establishment and routine use of high-throughput, high-precision, field-based/field-relevant phenotyping approaches, (2) development of molecular tools with which to track and combine beneficial alleles controlling RSA, and perhaps most critically, (3) detailed knowledge of which RSA are best suited to a given agricultural environment and to the wider genetic architecture of the germplasm used in any specific breeding programme. We expect the coming years will most likely firstly see the molecular characterization of increasing numbers of wheat RSA genes, providing the research community with multiple entry points into the genetic networks that underlie wheat RSA, as well as rapid approaches with which to integrate this knowledge into the targeted design of RSA ideotypes. These include advanced modelling and simulation capabilities to reveal promising RSA-component trait configurations that can be targeted in breeding programmes. Once available, such resources will allow the assessment of specific RSA ideotypes across multiple environments, providing the knowledge base from which these can be most confidently incorporated into future breeding programmes. Over this period, we believe that the ideal of high-precision in-field root phenotyping will most likely be tackled via the continued development of approaches that overlay multiple layers of phenotypic data from direct and indirect measurements of root performance, combined with high-power computing and AI approaches. Of course, these idealized outcomes are composed of a continuum of constitutive advances in research and innovation, and the steps along the way will offer opportunities for immediate practical use for crop breeders. For example, Richard et al. (2018) have recently demonstrated the potential of direct selection in early segregating generations by selecting individual plants contrasting for seminal root angle, which resulted in a significant shift in both phenotype and allele frequency in derived populations. Importantly, the critical steps listed above come together as phenotypic datasets that could be used to enrich functional-structural models that drive RSA computer simulations (reviewed by Tracy et al. 2020). Advances in functional genomics, system biology, modelling and computing power will allow for a more comprehensive analysis of genotypic and phenotypic information to predict the outcome of different allelic combinations for RSA. As the accuracy of these stochastic models increases at the field and farming system level, breeders will be able to run thousands of potential simulated gene combinations before the chosen crosses are made and planted out for field evaluation.

To help support the overall goals outlined here, we have established an international project between researchers and breeders in the UK, Germany, Italy, Australia and Mexico that begins to investigate the three key factors we list above. Following the principles outlined in this review, our aim is to exploit the current advances in RSA gene characterization made in wheat within the consortium and the wider community and translate this into knowledge and wheat germplasm resources adapted to multiple growing environments and countries. In ongoing work, consortium members have created a panel of 80 wheat NILs comprising the four seedling RSA ideotypes depicted in Fig. 1 in four elite backgrounds, in order to test relationships to mature plant RSA and yield under field conditions in different environments. As wheat is a global commodity underpinning food security across the world, we advocate such approaches for the efficient advancement of our understanding of promising and workable below- and above-ground trait configurations, thus helping their efficient exploitation in crop breeding programmes around the world.

Acknowledgements Work described here is supported in part by the project Root ${ }^{y}$ - A root ideotype toolbox to support improved wheat yields funded by the IWYP Consortium (project IWYP122), via the following funding agencies: the GRDC in Australia (ID 9,176,855), the Biotechnology and Biological Sciences Research Council and the Department for International Development in the United Kingdom (BB/S012826/1). Michelle Watt holds the Adrienne Clarke Chair of Botany, which is supported through the University of Melbourne Botany Foundation.

Author Contribution statement All authors assisted in writing and editing the manuscript and contributed to the ideas contained within.

\section{Declarations}

Conflict of interest On behalf of all authors, Eric S. Ober states that there is no conflict of interest.

Open Access This article is licensed under a Creative Commons Attribution 4.0 International License, which permits use, sharing, adaptation, distribution and reproduction in any medium or format, as long as you give appropriate credit to the original author(s) and the source, provide a link to the Creative Commons licence, and indicate if changes were made. The images or other third party material in this article are included in the article's Creative Commons licence, unless indicated otherwise in a credit line to the material. If material is not included in the article's Creative Commons licence and your intended use is not permitted by statutory regulation or exceeds the permitted use, you will 
need to obtain permission directly from the copyright holder. To view a copy of this licence, visit http://creativecommons.org/licenses/by/4.0/.

\section{References}

Adamski NM, Borrill P, Brinton J, Harrington SA, Marchal C et al (2020) A roadmap for functional characterisation in crops with large genomes: lessons from polyploid wheat. eLife 9:e55646. https://doi.org/10.7554/eLife.55646

Aira M, Gómez-Brandón M, Lazcano C, Bååth E, Domínguez J (2010) Plant genotype strongly modifies the structure and growth of maize rhizosphere microbial communities. Soil Biol Biochem 42:2276-2281. https://doi.org/10.1016/j.soilbio.2010.08.029

Alahmad S, El Hassouni K, Bassi FM, Dinglasan E, Youssef C, Quarry G, Aksoy A, Mazzucotelli E, Al J, Able JA, Christopher J, VossFels KP, Hickey LT (2019) A major root architecture QTL responding to water limitation in durum wheat. Front Plant Sci 10:436. https://doi.org/10.3389/fpls.2019.00436

Alahmad S, Kang Y, Dinglasan E et al (2020) Adaptive traits to improve durum wheat yield in drought and crown rot environments. Int J Mol Sci 21:1-17. https://doi.org/10.3390/ijms211552 60

Alemu A, Feyissa T, Maccaferri M, Sciara G, Tuberosa R, Ammar K, Badebo A, Acevedo M, Letta T, Abeyo B (2021) Genome-wide association analysis unveils novel QTLs for seminal root system architecture traits in Ethiopian durum wheat. BMC Genom 22:20. https://doi.org/10.1186/s12864-020-07320-4

Allen AM, Winfield MO, Burridge AJ et al (2017) Characterization of a wheat breeders' array suitable for high-throughput SNP genotyping of global accessions of hexaploid bread wheat (Triticum aestivum). Plant Biotechnol J 15:390-401

Arai-Sanoh Y, Takai T, Yoshinaga S, Nakano H, Kojima M, Sakakibara H, Kondo M, Uga Y (2014) Deep rooting conferred by DEEPER ROOTING 1 enhances rice yield in paddy fields. Sci Rep 4:5563. https://doi.org/10.1038/srep05563

Ashraf A, Rehman OU, Muzammil S, Léon J, Naz AA, Rasool F, Ali GM, Zafar Y, Khan MR (2019) Evolution of Deeper Rooting 1 -like homoeologs in wheat entails the C-terminus mutations as well as gain and loss of auxin response elements. PLoS One 14:e0214145. https://doi.org/10.1371/journal.pone.0214145

Asseng S, Ewert F, Martre P et al (2015) Rising temperatures reduce global wheat production. Nat Clim Change 5:143-147. https:// doi.org/10.1038/nclimate2470

Atkinson JA, Hawkesford MJ, Whalley WR, Zhou H, Mooney SJ (2019a) Soil strength drought influences wheat root interactions with soil macropores. Plant Cell Environ 43:235-245. https:// doi.org/10.1111/pce.13659

Atkinson JA, Pound MP, Bennett MJ, Wells DM (2019b) Uncovering the hidden half of plants using new advances in root phenotyping. Curr Opin Biotechnol 55:1-8. https://doi.org/10.1016/j.copbio. 2018.06.002

Badri DV, Vivanco JM (2009) Regulation and function of root exudates. Plant Cell Environ 32:666-681. https://doi.org/10.1111/j. 1365-3040.2009.01926.x

Bai C, Ge Y, Ashton RW, Evans J, Milne A, Hawkesford MJ et al (2019) The relationships between seedling root screens, root growth in the field and grain yield for wheat. Plant Soil 440(12):311-326. https://doi.org/10.1007/s11104-019-04088-9

Bais HP, Weir TL, Perry LG, Gilroy S, Vivanco JM (2006) The role of root exudates in rhizosphere interactions with plants and other organisms. Annu Rev Plant Biol 57:233-266. https://doi.org/10. 1146/annurev.arplant.57.032905.105159
Bao A, Aggarwal P, Robbins NE II, Sturrock CJ, Thompson MC, Tan HQ, Tham C, Duan L, Rodriguez PL, Vernoux T, Mooney SJ, Bennett MJ, Dinneny JR (2014) Plant roots use a patterning mechanism to position lateral root branches toward available water. Proc Natl Acad Sci USA 111:9319-9324. https://doi.org/ 10.1073/pnas.1400966111

Bishopp A, Lynch JP (2015) The hidden half of crop yields. Nat Plants 1:15117. https://doi.org/10.1038/nplants.2015.117

Bobenrieth E, Wright B, Zeng D (2013) Stocks-to-use ratios and prices as indicators of vulnerability to spikes in global cereal markets. Agric Econ 44:43-52. https://doi.org/10.1111/agec.12049

Bohn M, Novais J, Fonseca R, Tuberosa R, Grift TE (2006) Genetic evaluation of root complexity in maize. Acta Agron Hung 54:291-303. https://doi.org/10.1556/AAgr.54.2006.3.3

Borrill P, Harrington SA, Uauy C (2019) Applying the latest advances in genomics and phenomics for trait discovery in polyploid wheat. Plant J 97:56-72. https://doi.org/10.1111/tpj.14150

Bustos-Korts D, Romagosa I, Borràs-Gelonch G, Casas AM, Slafer GA, van Eeuwijk F (2019) Genotype by environment interaction and adaptation. In: Savin R, Slafer GA (eds) Crop science. Springer, New York

Canè MA, Maccaferri M, Nazemi G, Salvi S, Francia R, Colalongo C, Tuberosa R (2014) Association mapping for root architectural traits in durum wheat seedlings as related to agronomic performance. Mol Breed 34:1629-1645. https://doi.org/10.1007/ s11032-014-0177-1

Chen Y, Palta J, Prasad PVV, Siddique KHM (2020) Phenotypic variability in bread wheat root systems at the early vegetative stage. BMC Plant Biol 20:185. https://doi.org/10.1186/ s12870-020-02390-8

Chimungu JG, Brown KM, Lynch JP (2019) Reduced root cortical cell file number improves drought tolerance in maize. Plant Physiol 166:1943. https://doi.org/10.1104/pp.114.249037

Cobb JN, Juma RU, Biswas PS, Arbelaez JD, Rutkoski J, Atlin G, Hagen T, Quinn M, Ng EH (2019) Enhancing the rate of genetic gain in public-sector plant breeding programs: lessons from the breeder's equation. Theor Appl Genet 132:627-645. https://doi. org/10.1007/s00122-019-03317-0

Cockram J, Mackay I (2018) Genetic mapping populations for conducting high-resolution trait mapping in plants. In: Varshney RK, Pandey MK, Chitikineni A (eds) Plant genetics and molecular biology. Springer, Cham

Cockram J, Mackay IJ, O'Sullivan DM (2007) The role of doublestranded break repair in the creation of phenotypic diversity at cereal VRN1 loci. Genetics 177(4):2535-2539. https://doi.org/ 10.1534/genetics.107.074765

Comas L, Becker S, Cruz VM, Byrne PF, Dierig DA (2013) Root traits contributing to plant productivity under drought. Front Plant Sci 4:442. https://doi.org/10.3389/fpls.2013.00442

Crocker TL, Hendrick RL, Ruess RW, Pregitzer KS, Burton AJ, Allen MF, Shan J, Morris LA (2003) Substituting root numbers for length: improving the use of minirhizotrons to study fine root dynamics. Appl Soil Ecol 23:127-135. https://doi.org/10.1016/ S0929-1393(03)00024-6

Debernardi JM, Tricoli DM, Ercoli MF, Hayta S, Ronald P, Palatnik J, Dubcovsky J (2020) A GRF-GIF chimeric protein improves the regeneration efficiency of transgenic plants. Nat Biotechnol 38:1274-1279. https://doi.org/10.1038/s41587-020-0703-0

Deery DM, Rebetzke GJ, Jimenez-Berni JA, Bovill WD, James RA, Condon AG, Furbank RT, Chapman SC, Fischer RA (2019) Evaluation of the phenotypic repeatability of canopy temperature in wheat using continuous-terrestrial and airborne measurements. Front Plant Sci. https://doi.org/10.3389/fpls.2019.00875

Delgado A, Hays DB, Bruton RK, Hn C, Novo A, Boi E, Selvaraj MG (2017) Ground penetrating radar: a case study for estimating root 
bulking rate in cassava (Manihot esculenta Crantz). Plant Methods 13:65. https://doi.org/10.1186/s13007-017-0216-0

Dreccer MF, Condon AG, Macdonald B, Rebetzke GJ, Awasi M-A, Borgognone MG, Peake A, Piñera-Chavez FJ, Hundt A, Jackway P, McIntyre CL (2020) Genotypic variation for lodging tolerance in spring wheat: wider and deeper root plates, a feature of low lodging, high yielding germplasm. Field Crop Res 258:107942. https://doi.org/10.1016/j.fcr.2020.107942

Ehdaie B, Whitkus RW, Waines JG (2003) Root biomass, water-use efficiency, and performance of wheat-rye translocations of chromosomes 1 and 2 in spring bread wheat 'Pavon.' Crop Sci 43:710-717. https://doi.org/10.2135/CROPSCI2003.7100

Ehdaie B, Merhaut DJ, Ahmadian S, Hoops AC, Khuong T, Layne AP, Waines JG (2010) Root system size influences water-nutrient uptake and nitrate leaching potential in wheat. J Agron Crop Sci 196:455-466. https://doi.org/10.1111/j.1439-037X.2010.00433.x

El Hassouni K, Alahmad S, Belkadi B, Filali-Maltouf A, Hickey LT, Bassi FM (2018) Root system architecture and its association with yield under different water regimes in durum wheat. Crop Sci 58:2331-2346. https://doi.org/10.2135/cropsci2018.01.0076

Fatima T, Arora NK (2019) Plant growth-promoting rhizospheric microbes for remediation of saline Soils. In: Arora NK, Kumar $\mathrm{N}$ (eds) Phyto and rhizo remediation. Springer, Singapore

Fradgley N, Evans G, Biernaskie JM, Cockram J, Marr EC, Oliver AG, Ober E, Jones H (2020) Effects of breeding history and crop management on the root architecture of wheat. Plant Soil 452:587-600. https://doi.org/10.1007/s11104-020-04585-2

Galindo-Castañeda T, Brown KM, Lynch JP (2018) Reduced root cortical burden improves growth and grain yield under low phosphorus availability in maize. Plant Cell Environ 41:1579-1592. https://doi.org/10.1111/pce.13197

Gallego-Bartolomé J (2020) DNA methylation in plants: mechanisms and tools for targeted manipulation. New Phytol 227(1):38-44

Gao Y, Lynch JP (2016) Reduced crown root number improves water acquisition under water deficit stress in maize (Zea mays L.). $\mathrm{J}$ Exp Bot 67:4545-4557. https://doi.org/10.1093/jxb/erw243

Gasparis S, Przyborowski M, Kała M, Nadolska-Orczyk A (2019) Knockout of the HvCKX1 or HvCKX3 gene in barley (Hordeum vulgare $\mathrm{L}$.) by RNA-guided Cas9 nuclease affects the regulation of cytokinin metabolism and root morphology. Cells 8(8):782. https://doi.org/10.3390/cells8080782

George TS, Brown LK, Ramsay L, White PJ, Newton AC, Bengough AG, Russell J, Thomas WTB (2014) Understanding the genetic control and physiological traits associated with rhizosheath production by barley (Hordeum vulgare). New Phytol 203:195-205. https://doi.org/10.1111/nph.12786

Gil-Humanes J, Wang Y, Liang Z, Shan Q, Ozuna CV, Sánchez-León S, Baltes NJ (2017) High-efficiency gene targeting in hexaploid wheat using DNA replicons and CRISPR/Cas9. Plant J 89(6):1251-1262. https://doi.org/10.1038/ncomms14261

Gioia T, Galinski A, Lenz H, Müller C, Lentz J, Heinz K, Briese C, Putz A, Fiorani F, Watt M, Schurr U, Nagel KA (2017) GrowScreen-PaGe, a non-invasive, high-throughput phenotyping system based on germination paper to quantify crop phenotypic diversity and plasticity of root traits under varying nutrient supply. Funct Plant Biol 44:76-93. https://doi.org/10.1071/FP16128

Gornall J, Betts R, Burke E, Clark R, Camp J, Willett K, Wiltshire A (2010) Implications of climate change for agricultural productivity in the early twenty-first century. Philos Trans R Soc B Biol Sci 365:2973-2989. https://doi.org/10.1098/rstb.2010.0158

Gutierrez M, Reynolds M, Klatt A (2010) Association of water spectral indices with plant and soil water relations in contrasting wheat genotypes. J Exp Bot 61:3291-3303. https://doi.org/10.1093/ jxb/erq 156

Haling RE, Brown LK, Bengough AG, Valentine TA, White PJ, Young IM, George TS (2014) Root hair length and rhizosheath mass depend on soil porosity, strength and water content in barley genotypes. Planta 239:643-651. https://doi.org/10.1007/ s00425-013-2002-1

Hall AJ, Richards RA (2013) Prognosis for genetic improvement of yield potential and water-limited yield of major grain crops. Field Crop Res 143:18-33. https://doi.org/10.1016/j.fcr.2012.05.014

Hammer GL, McLean G, van Oosterom E, Chapman S, Zheng B, Wu A, Doherty A, Jordan D (2020) Designing crops for adaptation to the drought and high-temperature risks anticipated in future climates. Crop Sci 60:605-621. https://doi.org/10.1002/csc2.20110

Han Y, Xin M, Huang K, Xu Y, Liu Z, Hu Z, Yao Y, Peng H, Ni Z, Sun Q (2015) Altered expression of TaRSL4 gene by genome interplay shapes root hair length in allopolyploid wheat. New Phytol 209:721-732. https://doi.org/10.1111/nph.13615

He X, Fang J, Li J, Qu B, Ren Y et al (2014) A genotypic difference in primary root length is associated with the inhibitory role of transforming growth factor-beta receptor-interacting protein-1 on root meristem size in wheat. Plant J 77:931-943. https://doi. org/10.1111/tpj.12449

Hecht VL, Temperton VM, Nagel KA, Rascher U, Pude R, Postma JA (2019) Plant density modifies root system architecture in spring barley (Hordeum vulgare L.) through a change in nodal root number. Plant Soil 439:1-22. https://doi.org/10.1007/ s11104-018-3764-9

Henry A, Chaves NF, Kleinman PJA, Lynch JP (2010) Will nutrientefficient genotypes mine the soil? Effects of genetic differences in root architecture in common bean (Phaseolus vulgaris L.) on soil phosphorus depletion in a low-input agro-ecosystem in Central America. Field Crop Res 115:67-78. https://doi.org/ 10.1016/j.fcr.2009.10.004

Hickey LT, Hafeez AN, Robinson H et al (2019) Breeding crops to feed 10 billion. Nat Biotechnol 37:744-754. https://doi.org/10. 1038/s41587-019-0152-9

Hochholdinger F, Feix G (1998) Early post-embryonic development is specifically affected in the maize mutant $l r t 1$. Plant J 16:247-255. https://doi.org/10.1046/j.1365-313x.1998. 00280.x

Hochholdinger F, Park WJ, Sauer M, Woll K (2004) From weeds to crops: genetic analysis of root development in cereals. Trends Plant Sci 9:42-48. https://doi.org/10.1016/tplants.2003.11.003

Hochholdinger F, Wen TJ, Zimmermann R, Chimot-Marolle P, da Costae SO, Bruce W, Lamkey KR, Wienand U, Schnable PS (2008) The maize (Zea mays $\mathrm{L}$.) roothairless 3 gene encodes a putative GPI-anchored, monocot-specific, COBRA-like protein that significantly affects grain yield. Plant J 54:888-98. https://doi.org/ 10.1111/j.1365-313X.2008.03459.x

Hochholdinger F, Peng Y, Marcon C (2018) Genetic control of root system development in maize. Trends Plant Sci 23:79-88. https:// doi.org/10.1016/j.tplants.2017.10.004

Howell T, Hale I, Jankuloski L, Nonafede M, Gilbert M, Dubcovsky J (2014) Mapping a region within the 1RS.1BL translocation in common wheat affecting grain yield and canopy water status. Theor Appl Genet 127:2695-2709. https://doi.org/10.1007/ s00122-014-2408-6

Howell T, Moriconi JI, Zhao X, Hegarty J, Fahima T, Santa-Maria GE, Dubcovsky J (2019) A wheat/rye polymorphism affects seminal root length and is associated with drought and waterlogging tolerance. J Exp Biol 70:4027-4037. https://doi.org/10.1093/jxb/ erz169

Hurd EA (1974) Phenotype and drought tolerance in wheat. Agric Meteorol 14:39-55. https://doi.org/10.1016/0002-1571(74) 90009-0

International Wheat Genome Sequencing Consortium (2018) Shifting the limits in wheat research and breeding using a fully annotated reference genome. Science 361:7191. https://doi.org/10.1126/ science.aar7191 
Jeudy C, Adrian M, Baussard C, Bernard C, Bernaud E, Bourion V et al (2016) RhizoTubes as a new tool for high throughput imaging of plant root development and architecture: test, comparison with pot grown plants and validation. Plant Methods 12(1):1-18. https://doi.org/10.1186/s13007-016-0131-9

Juroszek P, von Tiedemann A (2013) Climate change and potential future risks through wheat diseases: a review. Eur J Plant Pathol 136:21-33. https://doi.org/10.1007/s10658-012-0144-9

Kätterer T, Andrén O (2009) Predicting daily soil temperature profiles in arable soils in cold temperate regions from air temperature and leaf area index. Acta Agric Scand Sect B Soil Plant Sci 59:77-86. https://doi.org/10.1080/09064710801920321

Kelliher T, Starr D, Su X, Guozhu T, Chen Z, Carter J, Wittich PE, Dong S, Green J, Burch E, McCuiston J, Gu W, Sun Y, Strebe T, Roberts J, Bate NJ, Que Q et al (2019) One-step genome editing of elite crop germplasm during haploid induction. Nat Biotechnol 37:287-292. https://doi.org/10.1038/s41587-019-0038-x

Kim YC, Glick BR, Bashan Y, Ryu CM (2012) Enhancement of plant drought tolerance by microbes. In: Aroca R (ed) Plant responses to drought stress. Springer, Heidelberg

Kirkegaard JA, Lilley JM, Howe GN, Graham JM (2007) Impact of subsoil water use on wheat yield. Aust J Agric Res. https://doi. org/10.1071/AR06285

Kirschner GW, Rosignoli S, Vardanega I, Guo L, Imani J et al. (2021) ENHANCED GRAVITROPISM 2 encodes a STERILE ALPHA MOTIVE containing protein that controls root growth angle in barley and wheat. bioRxiv https://doi.org/10.1101/2021.01.23. 427880

Klein SP, Schneider HM, Perkins AC, Brown KM, Lynch JP (2020) Multiple integrated root phenotypes are associated with improved drought tolerance. Plant Physiol 183:1011. https://doi.org/10. 1104/pp.20.00211

Krasileva KV, Vasquez-Gross HA, Howell T, Bailey P, Paraiso F et al (2017) Uncovering hidden variation in polyploid wheat. Proc Natl Acad Sci U S A 114:E913-E921. https://doi.org/10.1073/ pnas. 1619268114

Kuzmanović L, Ruggeri R, Able JA, Bassi FM, Maccaferri M, Tuberosa R, De Vita P, Rossini F, Ceoloni C (2018) Yield performance of chromosomally engineered durum wheat-Thinopyrum ponticum recombinant lines in a range of contrasting rain-fed environments across three countries. bioRxiv https://doi.org/10. $1101 / 313825$

Lee JE, Neumann M, Duro DI, Schmid M (2019) CRISPR-based tools for targeted transcriptional and epigenetic regulation in plants. PLoS One 14(9):e0222778. https://doi.org/10.1371/journal.pone. 0222778

Lenaerts B, Collard BCY, Demont M (2019) Review: improving global food security through accelerated plant breeding. Plant Sci 287:110207. https://doi.org/10.1016/j.plantsci.2019.110207

Li J, Han Y, Liu L, Chen Y, Du Y, Zhang J, Sun H, Zhao Q (2015) Qrt9, a quantitative trait locus controlling root thickness and root length in upland rice. J Exp Bot 66:2723-2732. https://doi.org/ 10.1093/jxb/erv076

Li L, Hey S, Liu S, Liu Q, McNinch C, Hu H-C, Wen T-J, Marcon C, Paschold A, Bruce W, Schnable PS, Hochholdinger F (2016) Characterization of maize roothairless6 which encodes a D-type cellulose synthase and controls the switch from bulge formation to tip growth. Sci Rep 6:34395. https://doi.org/10.1038/srep3 4395

Li C, Zong Y, Wang Y et al (2018) Expanded base editing in rice and wheat using a Cas9-adenosine deaminase fusion. Genome Biol 19:59. https://doi.org/10.1186/s13059-018-1443-Z

Li L, Xu Y, Ren Y, Guo Z, Li J, Tong Y, Lin T, Cui D (2019a) Comparative proteomic analysis provides insights into the regulatory mechanisms of wheat primary root growth. Sci Rep 9:11741. https://doi.org/10.1038/s41598-019-47926-7

Li X, Ingvordsen CH, Weiss M, Rebetzke GJ, Condon AG, James RA, Richards RA (2019b) Deeper roots associated with cooler canopies, higher normalized difference vegetation index, and greater yield in three wheat populations grown on stored soil water. J Exp Bot 70:4963-4974. https://doi.org/10.1093/jxb/erz232

Liang Z, Chen K, Li T, Zhang Y, Wang Y, Zhao Q, Liu J et al (2017) Efficient DNA-free genome editing of bread wheat using CRISPR/Cas9 ribonucleoprotein complexes. Nat Commun 8(1):1-5. https://doi.org/10.1038/ncomms14261

Lilley JM, Kirkegaard JA (2011) Benefits of increased soil exploration by wheat roots. Field Crop Res. https://doi.org/10.1016/j. fcr.2011.03.010

Liu X, Dong X, Xue Q, Leskovar DI, Jifon J, Butnor JR, Marek T (2018) Ground penetrating radar (GPR) detects fine roots of agricultural crops in the field. Plant Soil 423:517-531. https://doi. org/10.1007/s11104-017-3531-3

Lopes MS, Reynolds MP (2010) Partitioning of assimilates to deeper roots is associated with cooler canopies and increased yield under drought in wheat. Funct Plant Biol 37:147-156. https:// doi.org/10.1071/FP09121

Luo H, Xu H, Chu C, He F, Fang S (2020) High temperature can change root system architecture and intensify root interactions of plant seedlings. Front Plant Sci 11:160. https://doi.org/10. 3389/fpls.2020.00160

Lynch J (1995) Root architecture and plant productivity. Plant Physiol 109:7-13. https://doi.org/10.1104/pp.109.1.7

Lynch JP (2013) Steep, cheap and deep: an ideotype to optimize water and $\mathrm{N}$ acquisition by maize root systems. Ann Bot 112:347-357. https://doi.org/10.1093/aob/mcs293

Lynch JP (2019) Root phenotypes for improved nutrient capture: an underexploited opportunity for global agriculture. New Phytol 223:548-564. https://doi.org/10.1111/nph.15738

Maccaferri M, El-Feki W, Nazemi G, Salvi S, Canè MA, Colalongo MC, Stefanelli S, Tuberosa R (2016) Prioritizing quantitative trait loci for root system architecture in tetraploid wheat. J Exp Bot 67:1161-1178. https://doi.org/10.1093/jxb/erw039

Mace ES, Singh V, Van Oosterom EJ, Hammer GL, Hunt CH, Jordan DR (2012) QTL for nodal root angle in sorghum (Sorghum bicolor L. Moench) co-locate with QTL for traits associated with drought adaptation. Theor Appl Genet 124:97-109. https://doi. org/10.1007/s00122-011-1690-9

Mairhofer S, Zappala S, Tracy SR, Sturrock C, Bennett M, Mooney SJ, Pridmore T (2012) RooTrak: automated recovery of threedimensional plant root architecture in soil from X-ray microcomputed tomography images using visual tracking. Plant Physiol 158(2):561-569

Makhoul M, Rambla C, Voss-Fels KP, Hickey LT, Snowdon RJ, Obermeier C (2020) Overcoming polyploid pitfalls: a user guide for effective SNP conversion into KASP markers in wheat. Theor Appl Genet 133:2413-2430. https://doi.org/10.1007/ s00122-020-03608-x

McCully ME (1999) Roots in soil: unearthing the complexities of roots and their rhizospheres. Annu Rev Plant Physiol Plant Mol Biol 50:695-718. https://doi.org/10.1146/annurev.arplant.50.1.695

Meng F, Ziang D, Zhu J, Li Y, Mao C (2019) Molecular mechanisms of root development in rice. Rice 12:1. https://doi.org/10.1186/ s12284-018-0262-x

Merchuk-Ovnat L, Barak V, Fahima T, Ordon F, Lidzbarsky GA, Krugman T, Saranga Y (2016) Ancestral QTL alleles from wild emmer wheat improve drought resistance and productivity in modern wheat cultivars. Front Plant Sci 7:00452. https://doi.org/ $10.3389 /$ fpls.2016.00452 
Merchuk-Ovnat L, Fahima T, Ephrath JE, Krugman T, Saranga T (2017) Ancestral QTL alleles from wild emmer wheat enhance root development under drought in modern wheat. Front Plant Sci 8:00703. https://doi.org/10.3389/fpls.2017.00703

Messina CD, Podlich D, Dong Z, Samples M, Cooper M (2011) Yield-trait performance landscapes: from theory to application in breeding maize for drought tolerance. J Exp Bot 62:855-868. https://doi.org/10.1093/jxb/erq329

Mickelbart MV, Hasegawa PM, Bailey-Serres J (2015) Genetic mechanisms of abiotic stress tolerance that translate to crop yield stability. Nat Rev Genet 16:237. https://doi.org/10.1038/nrg3901

Milner MJ, Craze M, Hope MS, Wallington EJ (2020) Turning up the temperature on CRISPR: increased temperature can improve the editing efficiency of wheat using CRISPR/Cas9. Front Plant Sci. https://doi.org/10.3389/fpls.2020.583374

Motte H, Vanneste S, Beeckman T (2019) Molecular and environmental regulation of root development. Annu Rev Plant Biol 70:465-488. https://doi.org/10.1146/annurev-arpla nt-050718-100423

Munns R, James RA, Xu B, Athman A, Conn SJ, Jordans C, Byrt CS, Hare RA, Tyerman SD, Tester M, Plett D, Gilliham M (2012) Wheat grain yield on saline soils is improved by an ancestral $\mathrm{Na}^{+}$transporter gene. Nat Biotechnol 30:360-364. https://doi. org/10.1038/nbt.2120

Nagel KA, Putz A, Gilmer F, Fischbach A, Pfeifer J et al (2012) GROWSCREEN-Rhizo is a novel phenotyping robot enabling simultaneous measurements of root and shoot growth for plants grown in soil-filled rhizotrons. Funct Plant Biol 39:891-904. https://doi.org/10.1071/FP12023

Nagel KA, Lenz H, Kastenholz B, Gilmer F, Averesch A, Putz A, Heinz K, Fischbach A, Scharr H, Fiorani F, Walter A, Schurr U (2020) The platform GrowScreen-Agar enables identification of phenotypic diversity in root and shoot growth traits of agar grown plants. Plant Methods 16:89. https://doi.org/10.1186/ s13007-020-00631-3

Nestler J, Wissuwa M (2016) Superior root hair formation confers root efficiency in some, but not all, rice genotypes upon $\mathrm{P}$ deficiency. Front Plant Sci 7:1935. https://doi.org/10.3389/fpls.2016.01935

Nestler J, Liu S, Wen T-J, Paschold A, Marcon C, Tang HM, Li D, Li L, Meeley RB, Sakai H, Bruce W, Schnable PS, Hochholdinger F (2014) Roothairless5, which functions in maize (Zea mays L.) root hair initiation and elongation encodes a monocot-specific NADPH oxidase. Plant J 79:729-740. https://doi.org/10.1111/ tpj. 12578

Nestler J, Keyes SD, Wissuwa M (2016) Root hair formation in rice (Oryza sativa L.) differs between root types and is altered in artificial growth conditions. J Exp Bot 67:3699-3708. https:// doi.org/10.1093/jxb/erw115

Nuttall JG, O'Leary GJ, Panozzo JF, Walker CK, Barlow KM, Fitzgerald GJ (2017) Models of grain quality in wheat: a review. Field Crop Res 202:136-145. https://doi.org/10.1016/j.fcr.2015.12.011

Ober ES, Werner P, Flatman E, Angus WJ, Jack P, Smith-Reeve L, Tapsell C (2014) Genotypic differences in deep water extraction associated with drought tolerance in wheat. Funct Plant Biol 41:1078-1086. https://doi.org/10.1071/FP14094

Osmont KS, Sibout R, Hardtke CS (2007) Hidden branches: developments in root system architecture. Annu Rev Plant Biol 58:93113. https://doi.org/10.1146/annurev.arplant.58.032806.104006

Overvoorde P, Fukaki H, Beeckman T (2010) Auxin control of root development. Cold Spring Harb Perspect Biol. https://doi.org/ 10.1101/cshperspect.a001537

Oyanagi A, Nakamoto T, Wada M (1993) Relationship between root growth angle of seedlings and vertical distribution of roots in the field in wheat cultivars. Jpn J Crop Sci 62:565-570. https://doi. org/10.1626/jcs.62.565
Passioura J (2006) The perils of pot experiments. Funct Plant Biol 33:1075-1079. https://doi.org/10.1071/FP06223

Passioura JB (2012) Phenotyping for drought tolerance in grain crops: when is it useful to breeders? Funct Plant Biol 39:851-859. https://doi.org/10.1071/FP12079

Piñera-Chavez FJ, Berry PM, Foulkes MJ, Jesson MA, Reynolds MP (2016) Avoiding lodging in irrigated spring wheat. I. Stem and root structural requirements. Field Crop Res 196:325-336. https://doi.org/10.1016/j.fcr.2016.06.009

Pinto S, Reynolds M (2015) Common genetic basis for canopy temperature depression under heat and drought stress associated with optimized root distribution in bread wheat. Theor Appl Genet 128:575-585. https://doi.org/10.1007/s00122-015-2453-9

Pinto RS, Reynolds MP, Mathews KL, McIntyre CL, Olivares-Villegas JJ, Chapman SC (2010) Heat and drought adaptive QTL in a wheat population designed to minimize confounding agronomic effects. Theor Appl Genet 121:1001-1021. https://doi. org/10.1007/s00122-010-1351-4

Placido DF, Campbell MT, Folsom JJ, Cui X, Kruger GR, Baenziger S, Walia H (2013) Introgression of novel traits from a wild wheat relative improves drought adaptation in wheat. Plant Physiol 161:1806-1819. https://doi.org/10.1104/pp.113. 214262

Placido DF, Sandhu J, Sato SJ, Nersesian N, Quach T, Clemente TE, Staswick PE, Walia H (2020) The LATERAL ROOT DENSITY gene regulates root growth during water stress in wheat. Plant Biotechnol J 18:1955-1968. https://doi.org/10.1111/pbi.13355

Poorter H, Fiorani F, Pieruschka R, Wojciechowski T, van der Putten WH, Kleyer M, Schurr U, Postma J (2016) Pampered inside, pestered outside? Differences and similarities between plants growing in controlled conditions and in the field. New Phytol 212:838-855. https://doi.org/10.1111/nph.14243

Powell N, Ji X, Ravash R, Edlington J, Dolferus R (2012) Yield stability for cereals in a changing climate. Funct Plant Biol 39:539-552. http://www.publish.csiro.au/paper/FP12078

Ramírez-González RH, Borrill P, Lang D et al (2018) The transcriptional landscape of polyploid wheat. Science 361:eaar6089

Rellán-Álvarez R, Lobet G, Dinneny JR (2016) Environmental control of root system biology. Annu Rev Plant Biol 67:619-642. https://doi.org/10.1146/annurev-arplant-043015-111848

Ren Y, He X, Liu D, Li J, Zhao X, Li B, Tong Y, Zhang A, Li Z (2012) Major quantitative trait loci for seminal root morphology of wheat seedlings. Mol Breed 30:139-148. https://doi. org/10.1007/s11032-011-9605-7

Rich SM, Watt M (2013) Soil conditions and cereal root system architecture: review and considerations for linking Darwin and Weaver. J Exp Bot 64:1193-1208. http://jxb.oxfordjournals. org/content/64/5/1193.abstract

Rich SM, Wasson AP, Richards RA, Katore T, Prashar R, Chowdhary R, Saxena DC, Mamrutha HM, Zwart A, Misra SC, Prasad SVS, Chatrath R, Christopher J, Watt M (2016) Wheats developed for high yield on stored soil moisture have deep vigorous root systems. Funct Plant Biol 43:173-188. https://doi.org/10. 1071/FP15182

Richard CA, Hickey LT, Fletcher S, Jennings R, Chenu K, Christopher JT (2015) High-throughput phenotyping of seminal root traits in wheat. Plant Methods 11:13. https://doi.org/10.1186/ s13007-015-0055-9

Richard C, Christopher J, Chenu K, Borrell A, Christopher M, Hickey L (2018) Selection in early generations to shift allele frequency for seminal root angle in wheat. Plant Genome. https://doi.org/10.3835/plantgenome2017.08.0071

Robertson DS (1985) A possible technique for isolating genic DNA for quantitative traits in plants. J Theor Biol 117:1-10

Robinson H, Kelly A, Fox G, Franckowiak J, Borrell A, Hickey L (2018) Root architectural traits and yield: exploring the 
relationship in barley breeding trials. Euphytica 214:151. https://doi.org/10.1007/s10681-018-2219-y

Roychoudhry S, Kieffer M, Del Bianco M, Liao C-Y, Weijers D, Kepinski S (2017) The developmental and environmental regulation of gravitropic setpoint angle in Arabidopsis and bean. Sci Rep 7:42664. https://doi.org/10.1038/srep42664

Salvi S, Giuliani S, Ricciolini C, Carraro N, Maccaferri M, Presterl T, Ouzunova M, Tuberosa R (2016) Two major quantitative trait loci controlling the number of seminal roots in maize comap with the root developmental genes rtcs and ruml. J Exp Bot 67:1149-1159. https://doi.org/10.1093/jxb/erw011

Sanguineti MC, Li S, Maccaferri M, Corneti S, Rotondo F, Chiari T, Tuberosa R (2007) Genetic dissection of seminal root architecture in elite durum wheat germplasm. Ann Appl Biol 151:291305. https://doi.org/10.1111/j.1744-7348.2007.00198.x

Scher S, Messori G (2019) How global warming changes the difficulty of synoptic weather forecasting. Geophys Res Lett 46:29312939. https://doi.org/10.1029/2018GL081856

Schmidt JE, Bowles TM, Gaudin ACM (2016) Using ancient traits to convert soil health into crop yield: impact of selection on maize root and rhizosphere function. Front Plant Sci 7:373. https://doi. org/10.3389/fpls.2016.00373

Schneider HM, Lynch JP (2020) Should root plasticity be a crop breeding target? Front Plant Sci 11:546. https://doi.org/10.3389/fpls. 2020.00546

Schneider HM, Klein SP, Hanlon MT, Nord EA, Kaeppler S, Brown KM, Warry A, Bhosale R, Lynch JP (2020) Genetic control of root architectural plasticity in maize. J Exp Bot 10:3185-3197. https://doi.org/10.1093/jxb/eraa084

Sebastian J, Yee M-C, Viana WG, Rellán-Álvarez R, Feldman M, Priest HD, Trontin C, Lee T, Jiang H, Baxter I, Mockler TC, Hochholdinger F, Brutnell TP, Dinneny JR (2016) Grasses suppress shootborne roots to conserve water during drought. Proc Natl Acad Sci U S A 113:8861-8866. https://doi.org/10.1073/pnas.160421113

Severini AD, Wasson AP, Evans JR, Richards RA, Watt M (2020) Root phenotypes at maturity in diverse wheat and triticale genotypes grown in three field experiments: relationships to shoot selection, biomass, grain yield, flowering time, and environment. Field Crop Res 255:107870. https://doi.org/10.1016/j.fcr.2020.107870

Shi J, Tong Y (2020) TaLAMP1 plays key roles in plant architecture and yield response to nitrogen fertilizer in wheat. Front Plant Sci 11:598015. https://doi.org/10.3389/fpls.2020.598015

Shi J, Gao H, Wang H, Lafitte HR, Archibald R et al (2017) ARGOS 8 variants generated by CRISPR-Cas9 improve maize grain yield under field drought stress conditions. Plant Biotechnol J 15(2):207-216. https://doi.org/10.1111/pbi.12603

Shorinola O, Kaye R, Golan G, Peleg Z, Kepinski S, Uauy C (2019) Genetic screening for mutants with altered seminal root numbers in hexaploid wheat using a high-throughput root phenotyping platform. G3 9:2799-2809. https://doi.org/10.1534/g3.119. 400537

Sinclair TR, Manandhar A, Shekoofa A, Rosas-Anderson P, Bagherzadi L, Schoppach R, Sadok W, Rufty TW (2017) Pot binding as a variable confounding plant phenotype: theoretical derivation and experimental observations. Planta 245:729-735. https://doi.org/ 10.1007/s00425-016-2641-0

Soriano JM, Alvaro F (2019) Discovering consensus genomic regions in wheat for root-related traits by QTL meta-analysis. Sci Rep 9:10537. https://doi.org/10.1038/s41598-019-47038-2

Steele KA, Price AH, Witcombe JR, Shrestha R, Singh BN, Gibbons JM, Virk DS (2013) QTLs associated with root traits increase yield in upland rice when transferred through marker-assisted selection. Theor Appl Genet 126:101-108. https://doi.org/10. 1007/s00122-012-1963-y

Suzuki M, Sato Y, Wu S, Kang B-H, McCarty DR (2015) Conserved functions of the MATE transporter BIG EMBRYO1 in regulation of lateral organ size and initiation rate. Plant Cell 27:2288-2300. https://doi.org/10.1105/tpc. 15.00290

Svane SF, Jensen CS, Thorup-Kristensen K (2019) Construction of a large-scale semi-field facility to study genotypic differences in deep root growth and resources acquisition. Plant Methods 15:26. https://doi.org/10.1186/s13007-019-0409-9

Tadesse W, Sanchez-Garcia M, Assefa SG, Amri A, Bishaw Z, Ogbonnaya FC, Baum M (2019) Genetic gains in wheat breeding and its role in feeding the world. Crop Breed Genet Genomics 1:e190005. https://doi.org/10.20900/cbgg20190005

Taramino G, Sauer M, Stauffer JL Jr, Multani D, Niu X, Sakai H, Hochholdinger F (2007) The maize (Zea mays L.) RTCS gene encodes a LOB domain protein that is a key regulator of embryonic seminal and post-embryonic shoot-borne root initiation. Plant $\mathbf{J}$ 50:649-659. https://doi.org/10.1111/j.1365-313X.2007.03075.x

Taylor I, Lehner K, McCaskey E, Nirmal N, Ozkan-Aydin Y, Murray-Cooper M, Jain R, Hawkes EW, Ronald PC, Goldman DI, Benfey PN (2020). Mechanism and function of root circumnutation. bioRxiv https://doi.org/10.1101/2020.05.04.075127

Toal TW, Ron M, Gibson D, Kajala K, Splitt B, Johnson LS, Miller ND, Slovak R, Gaudinier A, Patel R, de Lucas M, Provart NJ, Spalding EP, Busch W, Kliebenstein DJ, Brady SM (2018) Regulation of root angle and gravitropism. G3 Genes Genom Genet 8:3841

Topp CN, Iyer-Pascuzzi AS, Anderson JT, Lee C-R, Zurek PR, Symonova O, Zheng Y, Bucksch A, Mileyko Y, Galkovskyi T, Moore BT, Harer J, Edelsbrunner H, Mitchell-Olds T, Weitz JS, Benfey PN (2013) 3D phenotyping and quantitative trait locus mapping identify core regions of the rice genome controlling root architecture. Proc Natl Acad Sci U S A 110:E1695-E1704. https://doi.org/10.1073/pnas.1304354110

Tracy SR, Nagel KA, Postma JA, Fassbender H, Wasson A, Watt M (2020) Crop improvement from phenotyping roots: highlights reveal expanding opportunities. Trends Plant Sci 25:105-118. https://doi.org/10.1016/j.tplants.2019.10.015

Uga Y, Sugimoto K, Ogawa S, Rane J, Ishitani M, Hara N, Kitomi Y, Inukai Y, Ono K, Kanno N, Inoue H, Takehisa H, Motoyama R, Nagamura Y, Wu J, Matsumoto T, Takai T, Okuno K, Yano M (2013) Control of root system architecture by DEEPER ROOT$I N G 1$ increases rice yield under drought conditions. Nat Genet 45:1097-1102. https://doi.org/10.1038/ng.2725

van Oosterom EJ, Yang Z, Zhang F, Deifel KS, Cooper M, Messina CD, Hammer GL (2016) Hybrid variation for root system efficiency in maize: potential links to drought adaptation. Funct Plant Biol 43:502-511. https://doi.org/10.1071/FP15308

Villareal RL, Rajaram S, Mujeeb-Kazi A, Toro E (1991) The effect of chromosome $1 \mathrm{~B} / 1 \mathrm{R}$ translocation on the yield potential of certain spring wheats (Triticum aestivum L.). Plant Breed 106:77-81. https://doi.org/10.1111/j.1439-0523.1991.tb004 82.x

von Behrens I, Komatsu M, Zhang Y, Berendzen KW, Niu X, Sakai H, Taramino G, Hochholdinger F (2011) Rootless with undetectable meristem 1 encodes a monocot-specific AUX/IAA protein that controls embryonic seminal and post-embryonic lateral root initiation in maize. Plant J 66:341-353. https://doi.org/10.1111/j. 1365-313X.2011.04495.X

Voss-Fels KP, Qian L, Parra-Londono S, Uptmoor R, Frisch M, Keeble-Gagnre G, Appels R, Snowdon RJ (2017) Linkage drag constrains the roots of modern wheat. Plant Cell Environ 40:717725. https://doi.org/10.1111/pce. 12888

Voss-Fels KP, Robinson H, Mudge SR, Richard C, Newman S et al (2018) VERNALIZATION1 modulates root system architecture in wheat and barley. Mol Plant 11:226-229

Voss-Fels KP, Stahl A, Wittkop B et al (2019) Breeding improves wheat productivity under contrasting agrochemical input levels. Nat Plants 5:706-714. https://doi.org/10.1038/s41477-019-0445-5 
Waite JM, Collum TD, Dardick C (2020) AtDRO1 is nuclear localized in root tips under native conditions and impacts auxin localization. Plant Mol Biol 103:197-210. https://doi.org/10.1007/ s11103-020-00984-2

Walkowiak S, Gao L, Monat C, Haberer G, Kassa MT, Brinton J, Ramirez-Gonzalez RH, Kolodziej MC, Delorean E, Thambugala D et al (2020) Multiple wheat genomes reveal global variation in modern breeding. Nature. https://doi.org/10.1038/ s41586-020-2961-X

Wang Y, Meng Z, Liang C, Meng Z, Wang Y, Sun G, Zhu T et al (2017) Increased lateral root formation by CRISPR/Cas9-mediated editing of arginase genes in cotton. Sci China Life Sci 60(5):524527. https://doi.org/10.1007/s11427-017-9031-y

Wang J, Wang R, Mao X, Li L, Chang X, Zhang X, Jing R (2019) TaARF4 genes are linked to root growth and plant height in wheat. Ann Bot 124:903-915. https://doi.org/10.1093/aob/ mcy 218

Wasson A, Bischof L, Zwart A, Watt M (2016) A portable fluorescence spectroscopy imaging system for automated root phenotyping in soil cores in the field. J Exp Bot 67(4):1033-1043. https://doi. org/10.1093/jxb/erv570

Wasson AP, Nagel KA, Tracy S, Watt M (2020) Beyond digging: noninvasive root and rhizosphere phenotyping. Trends Plant Sci 25:119-120. https://doi.org/10.1016/j.tplants.2019.10.011

Watson A, Ghosh S, Williams MJ, Williams MH, Cuddy WS et al (2018) Speed breeding is a powerful tool to accelerate crop research and breeding. Nat Plants 4:23-29

Watt M, McCully M, Canny M (1994) Formation and stabilization of rhizosheaths of Zea mays L. effect of soil water content. Plant Physiol 106:179-186. https://doi.org/10.1104/pp.106.1.179

Watt M, Magee LJ, McCully ME (2008) Types, structure and potential for axial water flow in the deepest roots of field-grown cereals. New Phytol 178:135-146. https://doi.org/10.1111/j.1469-8137. 2007.02358.x

Wen TJ, Schnable PS (1994) Analyses of mutants of three genes that influence root hair development in Zea mays (Gramineae) suggest that root hairs are dispensable. Am J Bot 81:833-842. https://doi.org/10.1002/j.1537-2197.1994.tb15564.x

Wen T-J, Hochholdinger F, Sauer M, Bruce W, Schnable PS (2005) The roothairless 1 gene of maize encodes a homolog of sec3, which is involved in polar exocytosis. Plant Physiol 138:1637-1643. https://doi.org/10.1104/pp.105.062174

Whalley WR, Watts CW, Gregory AS, Mooney SJ, Clark LJ, Whitmore AP (2008) The effect of soil strength on the yield of wheat. Plant Soil 306:237-247. https://doi.org/10.1007/s11104-008-9577-5

Whalley WR, Binley A, Watts CW, Shanahan P, Dodd IC, Ober ES, Ashton RW, Webster CP, White RP, Hawkesford MJ (2017)
Methods to estimate changes in soil water for phenotyping root activity in the field. Plant Soil 415:407-422. https://doi.org/10. 1007/s11104-016-3161-1

Whipps JM, Lynch JM (1983) Substrate flow and utilization in the rhizosphere of cereals. New Phytol 95:605-623. https://doi.org/ 10.1111/j.1469-8137.1983.tb03525.x

Xu C, Tai H, Saleem M, Ludwig Y, Majer C, Berendzen KW, Nagel KA, Wojciechowski T, Meeley RB, Taramino G, Hochholdinger F (2015) Cooperative action of the paralogous maize lateral organ boundaries (LOB) domain proteins RTCS and RTCL in shoot-borne root formation. New Phytol 207:1123-1133. https:// doi.org/10.1111/nph.13420

Yan L, Loukoianov A, Tranquilli G, Helguera M, Fahima T, Dubcovsky J (2003) Positional cloning of the wheat vernalization gene VRN1. Proc Natl Acad Sci U S A 100:6263-6268. https://doi. org/10.1073/pnas.0937399100

York LM, Slack S, Bennett MJ, Foulkes MJ (2018) Wheat shovelomics I: a field phenotyping approach for characterising the structure and function of root systems in tillering species. bioRxiv https:// doi.org/10.1101/280875

Yu P, Hochholdinger F (2018) The role of host genetic signatures on root-microbe interactions in the rhizosphere and endosphere. Front Plant Sci 9:1896. https://doi.org/10.3389/fpls.2018.01896

Zampieri M, Ceglar A, Dentener F, Toreti A (2017) Wheat yield loss attributable to heat waves, drought and water excess at the global, national and subnational scales. Environ Res Lett 12:064008. https://doi.org/10.1088/1748-9326/aa723b

Zhang H, Kim M-S, Sun Y, Dowd SE, Shi H, Paré PW (2008) Soil bacteria confer plant salt tolerance by tissue-specific regulation of the sodium transporter HKT1. Mol Plant Microbe Interact 21:737-744. https://doi.org/10.1094/MPMI-21-6-0737

Zhu H, Li C, Gao C (2020) Applications of CRISPR-Cas in agriculture and plant biotechnology. Nat Rev Mol Cell Biol 21:661-677. https://doi.org/10.1038/s41580-020-00288-9

Zickenrott I-M, Woche SK, Bachmann J, Ahmed MA, Vetterlein D (2016) An efficient method for the collection of root mucilage from different plant species-a case study on the effect of mucilage on soil water repellency. J Plant Nutr Soil Sci 179:294-302. https://doi.org/10.1002/jpln.201500511

Publisher's Note Springer Nature remains neutral with regard to jurisdictional claims in published maps and institutional affiliations. 